\title{
Temporal variation in depth to water table and hydrochemistry in three raised bogs and their laggs in coastal British Columbia, Canada
}

\section{S. A. Howie ${ }^{1}$ and H. J. van Meerveld ${ }^{2}$}

${ }^{1}$ Simon Fraser University, Geography Department, 8888 University Drive, Burnaby, V5A 1S6, BC, Canada

${ }^{2}$ VU University Amsterdam, Critical Zone Hydrology Group, De Boelelaan 1085, 1081HV Amsterdam, The Netherlands

Received: 11 December 2012 - Accepted: 13 December 2012

- Published: 20 December 2012

Correspondence to: S. A. Howie (sarah_howie@sfu.ca)

Published by Copernicus Publications on behalf of the European Geosciences Union.

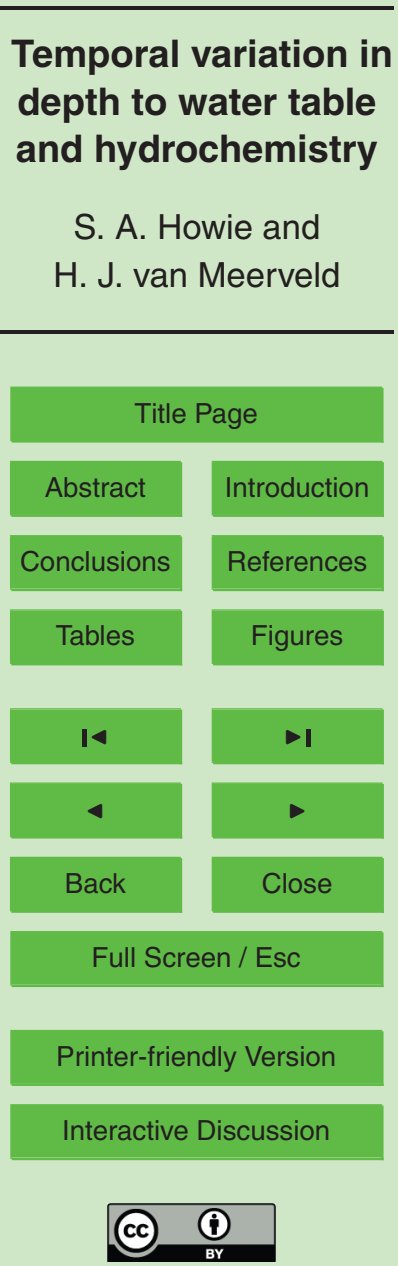




\section{Abstract}

The laggs of three raised bogs in coastal British Columbia were studied in 2010-2012 to determine the temporal variation in depth to water table and hydrochemistry. The lagg is an integral, but rarely studied, part of a raised bog that helps to maintain the 5 water mound in the bog and provides a buffer for runoff from adjacent mineral areas. Depth to water table measurements in 25 piezometers displayed similar annual fluctuations, with the highest water table in winter and the lowest at the end of summer. The smallest fluctuations in depth to water table were recorded closest to the bog centre, and the largest fluctuations in the laggs and adjacent mineral soil sites. Removal of a mature forest stand on one of the study transects resulted in a "watering-up" of the lagg site; the mean water level between August and November increased by $8 \mathrm{~cm}$ from 2010 to 2011 , and by up to $27 \mathrm{~cm}$ during the driest time of the year. $\mathrm{pH}, \mathrm{pH}$-corrected electrical conductivity, and $\mathrm{Na}^{+}$and $\mathrm{Mg}^{2+}$ concentrations varied little during the study period, whereas $\mathrm{Ca}^{2+}, \mathrm{K}^{+}, \mathrm{Cl}^{-}$, and $\mathrm{DOC}$ concentrations and acidity were more variable.

\section{Introduction}

Raised bogs form where precipitation is relatively evenly distributed throughout the year, and where annual precipitation exceeds potential evapotranspiration in most years (Schouten, 2002). Due to the dependence on precipitation, hydrological processes in raised bogs are closely linked to the amount, intensity, and distribution of precipitation. While discharge from the bog is strongly influenced by precipitation in the wet season, evapotranspiration is a major control on water in the acrotelm during the dry season (Wheeler et al., 1995). During moderate to large rainfall events, water levels in raised bogs tend to rise rapidly (Malmer, 1986). Correspondingly, water levels often decrease rapidly during dry periods due to evapotranspiration and relatively rapid lateral discharge through acrotelmic peat with a high hydraulic conductivity near the bog surface (Damman, 1986; Malmer, 1986; Holden, 2005). This repeating and predictable
HESSD

9, 14065-14107, 2012

Temporal variation in depth to water table and hydrochemistry

S. A. Howie and

H. J. van Meerveld

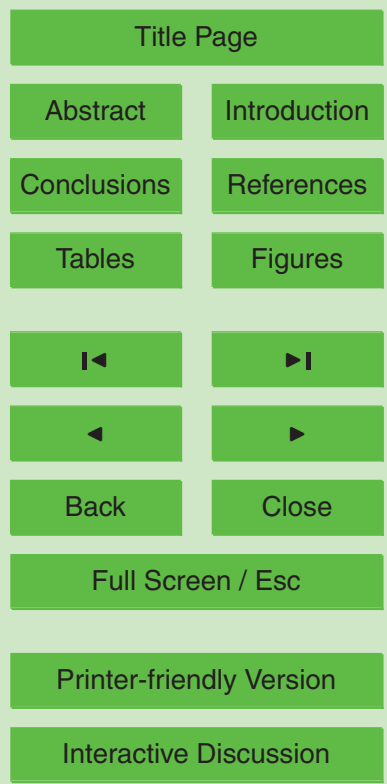


cycle of water level fluctuations over time is known as the "hydroperiod" (Rydin and Jeglum, 2006). In undisturbed raised bogs, the annual fluctuation of the water table is about $30 \mathrm{~cm}$, which is much smaller than in the adjacent mineral soils where the fluctuations can be closer to $50-150 \mathrm{~cm}$ (Schouten, 2002).

5 In temperate coastal regions, the highest water table in raised bogs occurs in winter, during periods of heavy rainfall, and the lowest in summer when there is little precipitation (Damman, 1986; Egglesmann et al., 1993). In contrast, bogs that experience extended periods of freezing in winter have the lowest water levels near the end of winter, because snow accumulates on the frozen bog surface and the bog continues to drain 10 until spring snowmelt (Damman, 1986). In both climates, evapotranspiration losses are largest during summer. The standard annual hydroperiod in southern coastal British Columbia (BC), Canada, has been established for Burns Bog (Howie et al., 2009a) and five eastern Vancouver Island bogs (Golinski, 2004). In general, the water table is at its highest and most stable level near the bog surface between October and March, 15 and declines from April onwards in response to decreased precipitation and increased evapotranspiration. It reaches a low point in September, and increases rapidly to the high winter water level in response to rainfall in September or October (Howie et al., 2009a; Golinski, 2004). The depth of the low point of the water table is variable between years and dependent on the extent of the summer drought period, but is generally 30$40 \mathrm{~cm}$ below the bog surface for a healthy bog (Schouwenaars and Vink, 1992). Similar annual fluctuations have been recorded for bogs in Europe (e.g. Egglesman et al., 1993).

Depth to water table measurements are the most common form of hydrological monitoring in bogs because they reflect the entire water balance, the individual components of which are much more difficult to measure (Bragg, 2002). In places where bogs are at their climatic limit, or where bogs have been drained, mined, or afforested, the fluctuation of the water table can be an important indicator of the ecological health and future trajectory of the bog ecosystem. Depth to water table is closely related to plant form, distribution, and growth (Rydin and Jeglum, 2006). If the summer water table
HESSD

9, 14065-14107, 2012

\section{Temporal variation in depth to water table and hydrochemistry}

S. A. Howie and

H. J. van Meerveld

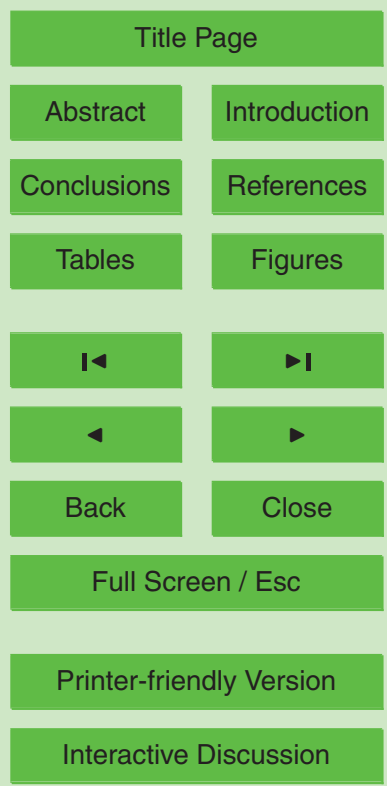


frequently drops more than $40 \mathrm{~cm}$ below the surface, non-bog species such as Betula may outcompete Sphagnum, the main peat-forming species in raised bogs, due to their ability to tolerate a more widely fluctuating water table (Price et al., 2003). A high water table supports the soil moisture and soil-water pressure required for survival of Sphag5 num colonies. Most Sphagnum colonies grow in places where volumetric soil moisture is above $50 \%$, and where soil-water pressure is greater than $-100 \mathrm{~cm}$ (Lavoie et al., 2003). Drier conditions prevent capillary movement of water to the bog surface, and since the non-vascular Sphagnum cannot survive long periods of drought and desiccation, this ultimately leads to the death of Sphagnum colonies (Lavoie et al., 2003; 10 Price et al., 2003). Drainage to facilitate peat mining, agriculture, or other activities lowers the water table, and can also result in irreversible changes to peat structure, including surface subsidence, compression, and oxidation, leading to changes in the hydraulic conductivity and a lower water retention capacity of the peat (Hobbs, 1986; Price et al., 2003; Holden et al., 2004). These conditions pose significant challenges 15 for the regeneration of Sphagnum, and may lead to the establishment of alternate plant communities (e.g. forest).

The lagg is the transition zone at the margin of a raised bog, receiving water from both the bog and the surrounding mineral soil. Due to the lower peat depth in the lagg, and its location at the margin of the bog, the lagg of a raised bog is often the first damaged by conversion to other land uses (e.g. agricultural, industrial). However, the lagg is an integral element of a raised bog because a high water table in the lagg helps to maintain the water mound of the bog by reducing the outward hydraulic gradient (Wheeler and Shaw, 1995). The fluctuation of the water table in undisturbed laggs may be less predictable than those in the bog due to the additional influence from upland runoff. The seasonal water level fluctuation is often smallest in the bog, greater in the outwardly-sloping rand forest at the bog margin, and greatest in the lagg fen (Damman, 1986). However, water table fluctuations in the lagg are also determined by the topographic conditions around the margin of the bog. Freely-draining laggs, and areas that receive comparatively little discharge from the bog and surrounding upland
HESSD

9, 14065-14107, 2012

\section{Temporal variation in depth to water table and hydrochemistry}

S. A. Howie and

H. J. van Meerveld

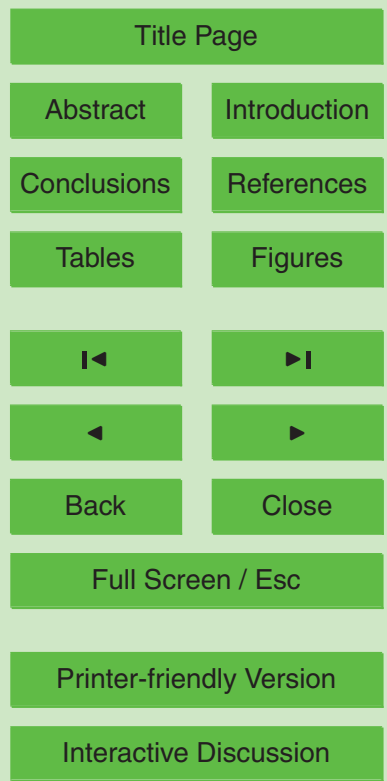


areas, may display a smaller water table fluctuation than laggs that are topographically constrained and experience frequent flooding (Howie and Tromp-van Meerveld, 2011).

The water table in peatlands is also affected by vegetation. Afforestation of a peatland may occur naturally in a drying climate, in response to disturbance (such as drainage or 5 peat mining), or as an intended land use change. The result of afforestation is typically a lower water table, due to increased interception and evapotranspiration losses (Fay and Lavoie, 2009). For example, Anderson et al. (2000) found a significant (mean: $7 \mathrm{~cm}$ ) decline in water table compared to the control site two years after the afforestation of a blanket bog. The opposite response occurs when trees are removed from peatlands; 10 the rise in water table associated with decreased interception and evapotranspiration is commonly referred to as the "watering-up" effect (Jeglum et al., 2003; Päivänen and Hånell, 2012). The rise in water table following clearcutting is, on average, about $5 \mathrm{~cm}$ (Roy et al., 2000). Heikurainen and Päivänen (1970) found a water table rise of 5-14 cm following clearcutting of a forested peatland in Finland; the lower the pre-clearcut water 15 table, the greater the water table rise following clearcutting. Roy et al. (1997) observed a mean water table rise of $4-6 \mathrm{~cm}$ after clearcutting an Ontario peatland.

The chemistry of surface and near-surface pore-water in raised bogs is influenced by the chemical characteristics of precipitation, as well as evapotranspiration and biological activity (Naucke et al., 1993). Ombrotrophic bogs are nutrient deficient because atmospheric deposition, i.e. precipitation and dustfall, is the sole source of nutrients (Damman, 1986). Concentrations in bog water are most similar to precipitation during times of heavy precipitation or snow melt (Damman and French, 1987). As the water table declines during summer, evapotranspiration and subsequent concentration of major ions in the peat generally results in higher concentrations of $\mathrm{Ca}^{2+}, \mathrm{Mg}^{2+}, \mathrm{Na}^{+}$, and $\mathrm{Cl}^{-}$, 25 which causes electrical conductivity to increase and $\mathrm{pH}$ to decrease (Proctor, 1995; Adamson et al., 2001). However, some studies have shown that undisturbed bogs are characterized by more stable concentrations of these elements than disturbed bogs, due to the ability of the Sphagnum-dominated surface of undisturbed bogs to buffer the chemical inputs (Andersen et al., 2010; Nelson et al., 2011) as a result of its high

\section{HESSD}

9, 14065-14107, 2012

\section{Temporal variation in depth to water table and hydrochemistry}

S. A. Howie and

H. J. van Meerveld

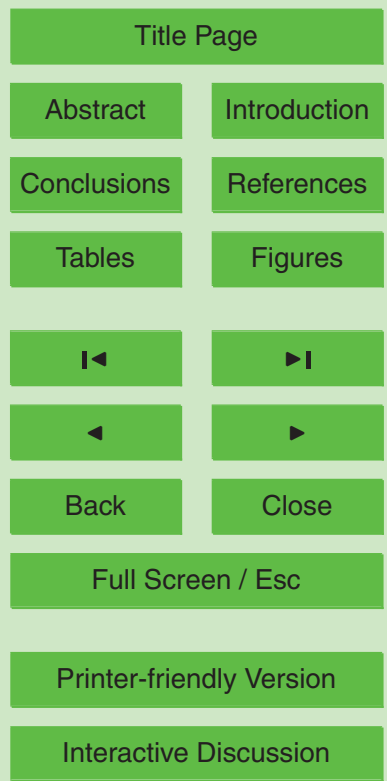


cation exchange capacity. For example, in a compilation of surface water data, Sjors and Gunnarsson (2002) noted that the effect of rainwater dilution in Swedish peatlands was temporary and that $\mathrm{pH}$ and cation concentrations in surface water were not highly variable, except for the strong dilution during snowmelt. Proctor (1994) observed that 5 water chemistry was most stable for a blanket bog in a wet, oceanic climate and most variable in a raised bog located in a drier climate. The few studies on the temporal variability in water chemistry in bogs usually have a sampling frequency of 1-2 months (e.g. Wieder, 1985; Proctor, 1994; Andersen et al., 2010). Little is known about how water chemistry changes in bogs over shorter time periods (i.e. hours or days) in re10 sponse to weather patterns.

Major cation and anion concentrations are typically higher at the bog margin than in the centre of the bog due to the influence of adjacent and underlying mineral soil (Naucke et al., 1993; Bragazza and Gerdol, 1999; Tahvanainen et al., 2002). For example, Bragazza et al. (2005) found for an Italian and Swedish raised bog that concen15 trations of $\mathrm{Ca}^{2+}, \mathrm{Mg}^{2+}, \mathrm{Al}^{3+}, \mathrm{Mn}^{2+}$, and $\mathrm{SiO}_{2}$ in pore-water were higher in the lagg than the bog. The $\mathrm{pH}$ of pore-water is generally also lowest in bogs, and higher in marginal lagg fens (Bubier, 1991; Bragazza et al., 2005). Balfour and Banack (2000) used these chemical patterns to develop a classification of water types in Burns Bog, BC, Canada: Type I (bog/ombrotrophic water), $\mathrm{pH} 3.5-5.5, \mathrm{Ca}^{2+} 0-3 \mathrm{mg} \mathrm{L}^{-1}$; Type II (lagg/transitional 20 water), $\mathrm{pH} 4.5-6.0, \mathrm{Ca}^{2+} 3-10 \mathrm{mg} \mathrm{L}^{-1}$; Type III (terrestrial/minerotrophic water), $\mathrm{pH}$ $>5.0-8.0, \mathrm{Ca}^{2+}>10 \mathrm{mg} \mathrm{L}^{-1}$. As concentrations of base cations and nutrients increase approaching the lagg, non-bog plant species such as sedges, deciduous shrubs, and trees are able to colonize and outcompete Sphagnum. For example, the lagg water type (Type II) classified by Balfour and Banack (2000) was often characterized by a dense thicket of Spiraea douglasii. It has also been suggested that the $\mathrm{Ca}: \mathrm{Mg}$ ratio may indicate the location of the mineral soil water limit at the edge of a raised bog, whereby a ratio higher than 1-2 signifies a transition from ombrotrophic to minerotrophic conditions (Naucke et al., 1993; Glaser et al., 1990; Proctor, 2003; Lähteenoja et al., 2009),
HESSD

9, 14065-14107, 2012

\section{Temporal variation in depth to water table and hydrochemistry}

S. A. Howie and

H. J. van Meerveld

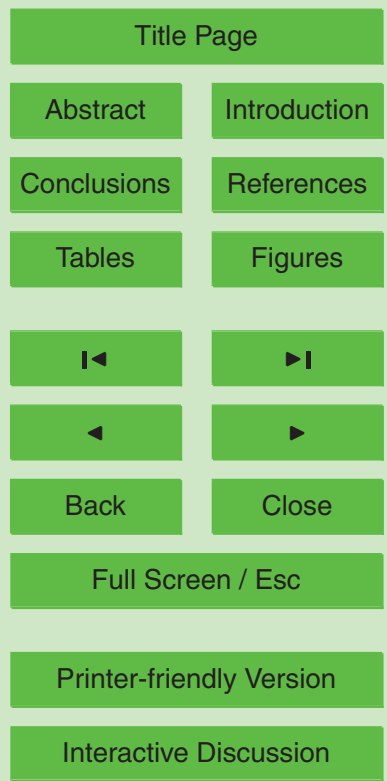


although the exact value varies depending on the chemical composition and amount of precipitation (Waughman, 1980; Shotyk, 1996).

The objectives of this study were: (i) to improve the knowledge of the temporal variation in depth to water table and pore-water chemistry in coastal raised bogs in BC, and 5 in particular how these changes relate to the rarely-studied marginal lagg, and (ii) to determine whether a single sampling event is sufficient to characterize the hydrochemistry of bogs and their associated laggs in coastal BC. More frequent measurements in a large number of bogs are often not feasible; if bog hydrochemistry can be approximated by a single sample, a larger number of sites can be surveyed. This would help 10 with establishing restoration plans for these bogs, as many of them are impacted by drainage or land use changes around the margins of the bog. Our hypothesis was that the water table in bogs follows a broadly similar pattern each year due to the close association between depth to the water table and precipitation (Malmer, 1986) and that the lagg of raised bogs has a similar hydroperiod as the adjacent open bog area. With 15 respect to hydrochemistry, our hypothesis was that hydrochemical analysis in early summer would be representative for the entire year because this time of year has neither extended dry periods nor high rainfall, which can cause concentrations to spike or drop (Vitt et al., 1995). Unexpected logging at one of the study sites allowed us to also study the effect of vegetation changes on the depth to water table.

\section{Study sites}

Raised bogs are a common feature in coastal British Columbia. Their distribution is determined primarily by climate (specifically the balance between precipitation and evapotranspiration) and the morphology of the land surface (National Wetlands Working Group - NWWG, 1988). In the Fraser River delta, 10-25\% of the land area is covered by wetlands; the surrounding Fraser River lowland contains 5-10\% wetlands. On Vancouver Island, wetlands make up less than $5 \%$ of the landscape. Further north along the coast, higher annual rainfall and lower temperatures results in wetlands in

\section{HESSD}

9, 14065-14107, 2012

\section{Temporal variation in depth to water table and hydrochemistry}

S. A. Howie and

H. J. van Meerveld

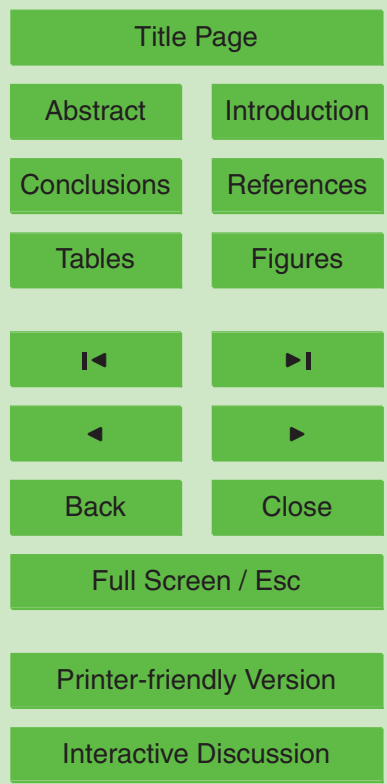


up to $75 \%$ of the land area (NWWG, 1988). Golinski (2004) developed a regional vegetative classification for Vancouver Island peatlands, and compared the hydrology and chemistry of disturbed and undisturbed peatlands. However, apart from this study, a few local studies by university classes (e.g. Trinity Western University), and monitor5 ing programs by wetland management agencies (e.g. Burns Bog, Delta, BC), little is known about seasonal water level and hydrochemical changes in bogs in southwestern BC. Therefore, Burns Bog (Delta, BC) was studied from June 2010-December 2012, Blaney Bog (Maple Ridge, BC) from June 2010-December 2011, and Campbell River Bog (Campbell River, BC) in May 2010 and May 2011 (Fig. 1).

10 Burns Bog is a 3000 ha raised bog situated on the Fraser River delta; it is bound to the north by the Fraser River and to the south by Boundary Bay. Peat harvesting between the 1930s and the mid-1980s resulted in an extensive network of drainage ditches and a lowered peat surface in the central area of the bog. Despite this disturbance, $29 \%$ of Burns Bog remains undisturbed; 2450 ha of the bog were purchased by 15 the local, regional, provincial, and federal government in 2004 as an ecological conservancy area. Much of the Burns Bog lagg has been lost to drainage, filling, and conversion to other land uses (i.e. agriculture, industry, and roads). However, some remnant laggs areas remain relatively undisturbed. Three of these remnant laggs were studied from June 2010-December 2011: Sherwood Forest (slough boundary), Cranwest (outwash to delta), and the Delta Nature Reserve (DNR) (upland) (Howie et al. 2009b) (Fig. 1). A portion of the Sherwood lagg was unexpectedly logged halfway through the study period. The logged area was approximately 4.7 ha in size, and dominated by a second growth stand $\left(\sim 500\right.$ stems ha $\left.^{-1}\right)$ of western red-cedar (Thuja plicata) ranging from 10-40 m (median: $28 \mathrm{~m}$ ) in height and 5-100 cm (median: $35 \mathrm{~cm}$ ) in diameter.

To compare data from this study with longer time series, results from three other piezometers in Burns Bog are reported here as well. For comparison of water table data, we include data from a piezometer that was installed in 2006 in an open bog site near the Sherwood transect (Fig. 1). For water chemistry, we present data from

\section{HESSD}

9, 14065-14107, 2012

\section{Temporal variation in depth to water table and hydrochemistry}

S. A. Howie and

H. J. van Meerveld

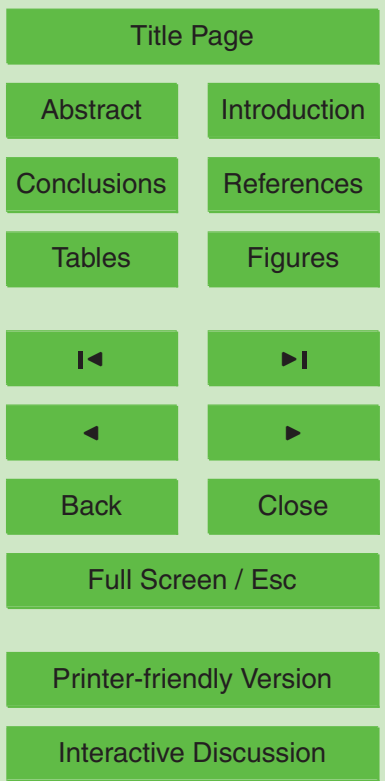


two piezometers (PF-100 and PF-200) installed in 2010 in the southeastern corner of Burns Bog. PF-100 and PF-200 are located in a bog forest dominated by Pinus contorta and Gaultheria shallon, 100 and $200 \mathrm{~m}$ from the bog margin, respectively (Fig. 1).

Blaney Bog is a 130 ha bog/fen complex in the Pitt River valley and is a rare example 5 of an undisturbed bog in the Greater Vancouver area. The wetland complex includes riparian, marsh, fen, and bog features (Gebauer, 2002). Approximately $10 \%$ of the wetland area consists of coalescing islands of raised bog that are developing over the fen matrix (Gebauer, 2002). The entire lagg of the developing bog remains intact, providing a unique opportunity to study two undisturbed lagg transition features: upland 10 forest and spring fen (Fig. 1).

The Campbell River site contains a complex of open bog, bog forest, fen, and swamp. The bog has been partially impacted by roads to the east and north, and possibly by logging in the adjacent upland, but the studied upland lagg on the west side of the bog appears to be relatively undisturbed.

Annual precipitation at Vancouver International Airport (YVR) (16 km from Burns Bog) was $1207 \mathrm{~mm}$ in 2010 and $1071 \mathrm{~mm}$ in 2011 (source: Environment Canada). For Blaney Bog (Haney UBC research forest weather station, approx. $1 \mathrm{~km}$ from Blaney Bog), annual precipitation was $2034 \mathrm{~mm}$ in 2010 and $1989 \mathrm{~mm}$ in 2011. Annual precipitation in Campbell River was $1904 \mathrm{~mm}$ in 2010 and $1378 \mathrm{~mm}$ in 2011. Total precipitation at YVR between 1 April and 1 September was $261 \mathrm{~mm}$ in 2010 and $288 \mathrm{~mm}$ in 2011. At Blaney Bog, 1 April-1 September total precipitation was $474 \mathrm{~mm}$ in 2010 and $644 \mathrm{~mm}$ in 2011. For the same time period, total precipitation in Campbell River was $304 \mathrm{~mm}$ in 2010 and $246 \mathrm{~mm}$ in 2011. Between 1 April and 1 September, mean air temperature at YVR was $14.6^{\circ} \mathrm{C}$ in 2010 and $13.9^{\circ} \mathrm{C}$ in $2011,14.2^{\circ} \mathrm{C}$ in 2010 and $12.8^{\circ} \mathrm{C}$ in 2011 at Blaney Bog, and $13.7^{\circ} \mathrm{C}$ in 2010 and $12.7^{\circ} \mathrm{C}$ in 2011 in Campbell River.

\section{Transects}

There were five sampling locations across each of the six studied lagg transects: (1) inside the bog ("bog"), (2) between the bog and lagg (closer to bog; "trans1"), (3) between

\section{HESSD}

9, 14065-14107, 2012

\section{Temporal variation in depth to water table and hydrochemistry}

S. A. Howie and

H. J. van Meerveld

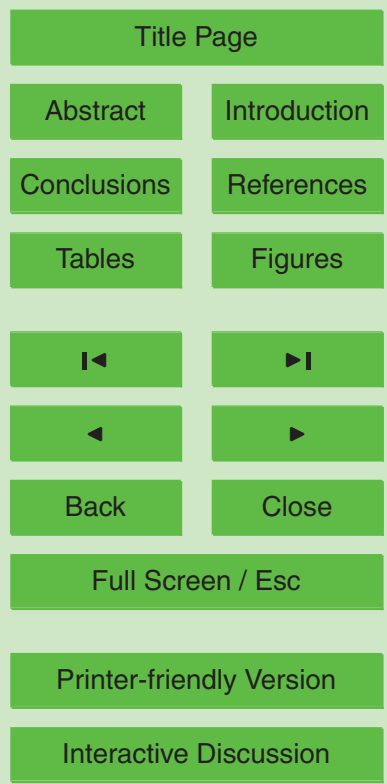


the bog and lagg (closer to lagg; "trans2"), (4) approximate centre of the lagg ("lagg"), and (5) outside the bog ("mineral"). These five locations were determined in the field based on vegetation characteristics that indicated the position along the transect. "Bog" was defined as Sphagnum-dominated heath, "lagg" was defined either as Spiraea5 dominated or containing larger shrubs and trees than the bog, and "outside" was defined as the forest surrounding the bog. In Burns Bog, there were two exceptions to this transect configuration: the Sherwood Forest transect contained a second "lagg" study location due to changes in vegetation across the lagg, and the Delta Nature Reserve transect contained two "lagg" locations (due to the presence of two different vegetative 10 lagg types) and no study location between the bog and lagg (due to the influence of a highway).

All locations were recorded with an Oregon 300 handheld GPS unit, accurate to 5 metres. The Blaney Bog and Campbell River transects were surveyed with a rod and level in March 2011 and May 2011, respectively. The Burns Bog transect elevations 15 were determined from LiDAR data collected in September 2008.

\section{Methods}

\subsection{Field methods}

Piezometers were installed at each study location on the transects to determine the depth to water table. The piezometers were $1.5 \mathrm{~m}$ long, $2.5 \mathrm{~cm}$ diameter Schedule 40 PVC pipe with a $40 \mathrm{~cm}$ slotted length at the bottom. The piezometers were installed in April/May 2010 in Burns Bog, in May 2010 in Campbell River Bog, and in June 2010 in Blaney Bog. The piezometers were purged twice 1-2 weeks prior to each sampling, with the exception of the Campbell River Bog piezometers, which were only given one day in 2010 and four days in 2011 to recharge prior to sampling. Depth to water table was measured in the piezometers with an electronic water level probe (Heron Instruments Little Dipper). Table 1 lists the frequency of the depth to water table
HESSD

9, 14065-14107, 2012

Temporal variation in depth to water table and hydrochemistry

S. A. Howie and

H. J. van Meerveld

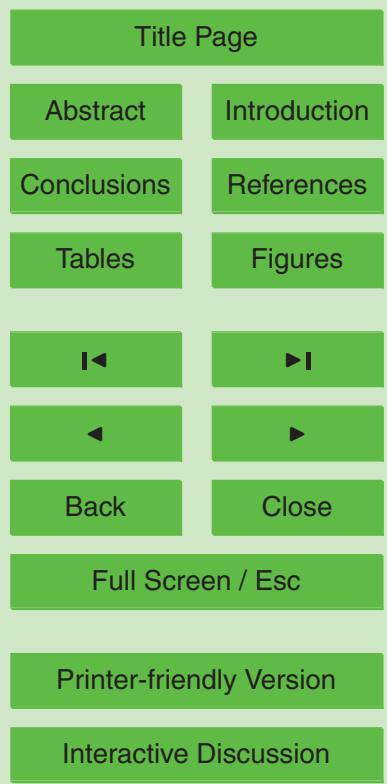


measurements for each transect. Depth to water table measurement frequency in the Sherwood transect increased to weekly between August 2011 and December 2011 to monitor the water table change in response to logging of the mature forest between the "lagg1" and "mineral" sites on the transect.

$5 \quad$ Electrical conductivity, $\mathrm{pH}$, and temperature were measured directly in the piezometers (top $10-15 \mathrm{~cm}$ of water column) with a WTW Multiline P4 water quality meter. The probes were rinsed with distilled water before each measurement. Electrical conductivity was compensated for $\mathrm{H}^{+}$concentrations using the following formula: $\mathrm{EC}_{\text {corr }}=\mathrm{EC}_{\text {measured }}-\mathrm{EC}_{\mathrm{H}}^{+}$, where $\mathrm{EC}_{\mathrm{H}}^{+}=3.49 \times 10^{5} \times 10^{-\mathrm{pH}}$, and $3.49 \times 10^{5}$ is the con10 version factor for field measurements standardized to $25^{\circ} \mathrm{C}$ by a handheld meter (Rydin and Jeglum, 2006). At Campbell River bog, the field $\mathrm{pH}$ meter failed in 2011, so pH was measured in the laboratory.

For Blaney Bog and Burns Bog DNR, sampling for cations, chloride, sulphate, acidity, dissolved organic carbon (DOC) was only done once (June 2011). For the other two 15 Burns Bog transects and at Campbell River Bog, water chemistry sampling was carried out in May/June of 2010 and 2011. A low-flow peristaltic pump (Global Water SP200) was used to collect water samples into plastic HDPE bottles. To avoid contamination of water samples, the plastic tubing of the peristaltic pump was rinsed with water from each site prior to sample collection and flushed prior to taking a sample. Samples were kept on ice and refrigerated until delivery to the Pacific Environmental Science Centre (North Vancouver, $\mathrm{BC}$ ), where they were analyzed for: $\mathrm{Ca}^{2+}, \mathrm{Mg}^{2+}, \mathrm{Na}^{+}, \mathrm{K}^{+}, \mathrm{SO}_{4}^{2-}$, $\mathrm{Cl}^{-}$, and DOC concentrations, and acidity. For Burns Bog and Blaney Bog, pore water concentrations were compared to 1986-1993 average concentrations in precipitation from YVR (Piteau Associates, 1994). For Campbell River Bog, pore water concentra-

tions were compared to 1978-1986 average concentrations in precipitation from Port Hardy (National Atmospheric Chemistry Database, 2012).

\section{HESSD}

9, 14065-14107, 2012

\section{Temporal variation in depth to water table and hydrochemistry}

S. A. Howie and

H. J. van Meerveld

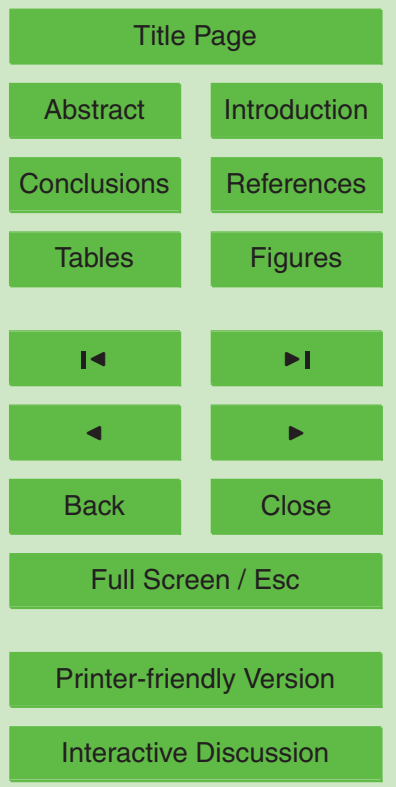




\subsection{Statistical methods}

Analysis of variance (ANOVA) was used to determine whether the variation in the hydrochemical characteristics over time, or across the transects, were statistically significant. Spearman rank correlation tests were performed between depth to water table, $5 \mathrm{pH}, \mathrm{EC}_{\text {corr }}$, and all other measured hydrochemical parameters. A significance level of 0.05 was used for all analyses.

\section{Results}

\subsection{Spatial and temporal water table fluctuations}

The depth to water table fluctuations increased across the transition from bog to forest between June 2010 and December 2011 in the "bog" sites ranged from 0.26-0.42 m, compared to $0.33-0.66 \mathrm{~m}$ in the transition sites between bog and lagg, $0.45-0.72 \mathrm{~m}$ in the lagg, and 0.41-0.79 m in the mineral sites (Table 2, Figs. 2, 3). Campbell River Bog was not included in this analysis because depth to water table was only measured in May. For comparison with a longer time series, Fig. 4 shows the water level fluctuations from 2006-2012 for a piezometer located $330 \mathrm{~m}$ north of the Sherwood forest "bog" site, in the same plant community. Similar to all the "bog" sites, the water table at this piezometer dropped to a maximum of approx. $30-40 \mathrm{~cm}$ below the bog surface over the six-year monitoring period.

\section{2 "Watering up" in Sherwood Forest}

A portion of the mature forest on the western side of the Sherwood transect was unexpectedly cut part way through the study period in May/June 2011. Two piezometers on the Sherwood transect were affected by the logging: "lagg1" and "lagg2" (Fig. 2). The result of this logging was a pronounced "watering-up" effect. The lowest measured
HESSD

9, 14065-14107, 2012

Temporal variation in depth to water table and hydrochemistry

S. A. Howie and H. J. van Meerveld

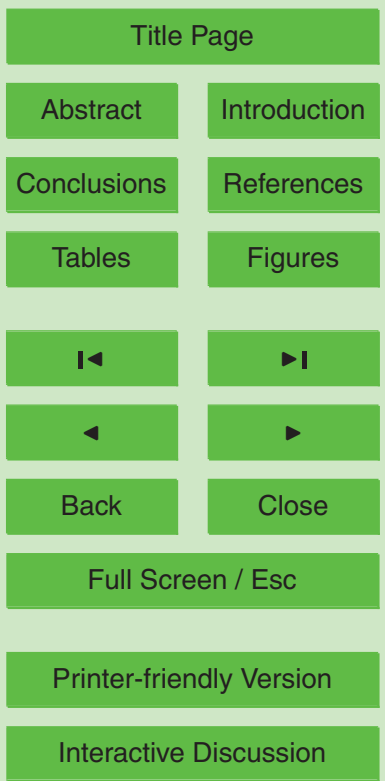


water table at the "lagg2" site, in the middle of the Sherwood clearcut, was $27 \mathrm{~cm}$ higher in 2011 than in 2010, whereas it was $10 \mathrm{~cm}$ higher in 2011 than in 2010 for the Cranwest "lagg" site and $0.5 \mathrm{~cm}$ lower for the DNR forested "lagg" site. The clearcut site showed a mean water table increase of $8 \mathrm{~cm}$ between August and November com5 pared to the pre-logged condition in 2010, whereas the mean water table was $13 \mathrm{~cm}$ lower in 2011 than in 2010 for the Cranwest lagg and $8 \mathrm{~cm}$ lower for the DNR forested lagg. The "lagg1" site, which was located at the edge of the cutblock, displayed a moderate water table increase of $11 \mathrm{~cm}$ in August 2011 compared to August 2010; the August-November mean water table increase compared to pre-logged conditions in 102010 was $4 \mathrm{~cm}$. In 2012, the late summer water table in the "lagg2" site was lower than in 2011, which may partly be attributed to the regeneration of a salal (Gaultheria shalIon) shrub layer and resulting increased evapotranspiration in the clearcut site in 2012. Mean air temperature at YVR for July and August was the same between 2011 and $2012\left(18^{\circ} \mathrm{C}\right)$, but there was less precipitation during this period in $2012(31 \mathrm{~mm})$ than 15 in 2011 (57 mm), which may in part also account for the lower water table in 2012.

\subsection{Seasonal variation in water chemistry}

There was little variation in field-measured $\mathrm{pH}$ during the study period from May 2010 to December 2011 (Table 3, Fig. 5). For all sites, $\mathrm{pH}$ varied by less than 0.85 over time. At $21 \%$ of the sites $\mathrm{pH}$ varied by more than 0.5 ; at $46 \%$ of the sites $\mathrm{pH}$ varied by $0.25-0.5$. All pH measurements taken in June/July were within 0.25 of the long term average. On average, the temporal variation was lowest in the "bog" sites, and increased approaching the lagg (Table 3). However, this trend was not clear for the individual transects; variability in $\mathrm{pH}$ increased across one transect (Blaney Bog - Upland), decreased across one transect (Campbell River), and fluctuated across the remaining

\section{HESSD}

9, 14065-14107, 2012

\section{Temporal variation in depth to water table and hydrochemistry}

S. A. Howie and

H. J. van Meerveld

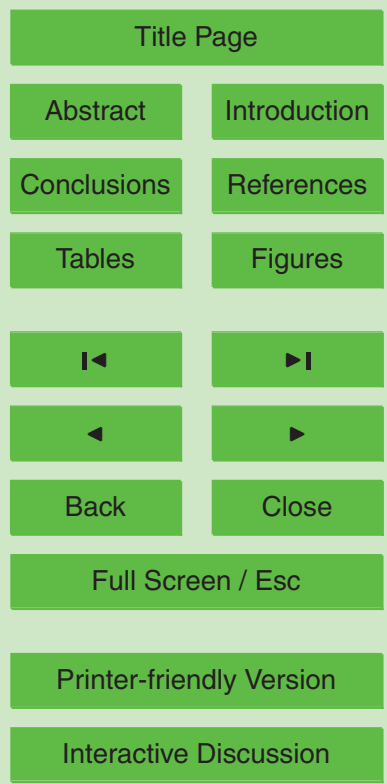


Temporal variation in $\mathrm{pH}$-corrected electrical conductivity $\left(\mathrm{EC}_{\text {corr }}\right)$ generally followed the variation in $\mathrm{pH}$ (Fig. 6), although $\mathrm{EC}_{\text {corr }}$ was more variable. At $28 \%$ of the sites $\mathrm{EC}_{\text {corr }}$ varied by $0-25 \mu \mathrm{Scm}^{-1}$ during the study period, at $44 \%$ of the sites it varied by $25-50 \mu \mathrm{Scm}^{-1}$, and at $28 \%$ of the sites it varied by $50-100 \mu \mathrm{Scm}^{-1}$. All measurements 5 taken in June/July were within $65 \mu \mathrm{S} \mathrm{cm}^{-1}$ of the long term average; $85 \%$ were within $25 \mu \mathrm{sm}^{-1}$ of the long term average. Average values from May are not reported here for $\mathrm{EC}_{\text {corr }}$ because this parameter was not measured in May 2010 due to equipment malfunction. The differences in $\mathrm{EC}_{\text {corr }}$ between the measurement dates were not statistically significant for any of the Burns Bog or Blaney Bog transects. For the Burns Bog 10 Sherwood transect, temporal variation in $\mathrm{EC}_{\text {corr }}$ was highest in the bog and decreased across the transect; the opposite trend was found for the Cranwest and DNR transects in Burns Bog. There was no clear spatial trend in temporal variability in $\mathrm{EC}_{\text {corr }}$ for the Blaney Bog transects.

Table 4 shows the results of the laboratory analyses for all six transects. Magnesium 15 and sodium concentrations were low and varied by less than $0.9 \mathrm{mg} \mathrm{L}^{-1}$ between years for all three multi-year transects. Calcium and potassium concentrations were more variable over time, with the difference between years ranging from $0-4.2 \mathrm{mg} \mathrm{L}^{-1}$ and $0.4-14.8 \mathrm{mgL}^{-1}$, respectively. Most sulphate concentrations were less than the laboratory detection limit of $0.5 \mathrm{mg} \mathrm{L}^{-1}$, so it is not possible to draw conclusions about its 20 temporal variability, except that it was low in both years. Changes in chloride concentrations, dissolved organic carbon concentrations, and acidity between years ranged from $0.5-8.1 \mathrm{mg} \mathrm{L}^{-1}, 0.9-16.6 \mathrm{mg} \mathrm{L}^{-1}$, and 1-34 $\mathrm{mg} \mathrm{CaCO}_{3} \mathrm{~L}^{-1}$, respectively. The relative change in concentration (= difference/mean) was lowest for sodium, and increased in the following order: $\mathrm{Na}^{+}, \mathrm{DOC}, \mathrm{Mg}^{2+}, \mathrm{Ca}^{2+}, \mathrm{Cl}^{-}$, acidity, $\mathrm{K}^{+}$. Spearman rank correla25 tion tests for all piezometers together revealed a significant positive correlation between depth to water table and: $\mathrm{EC}_{\mathrm{corr}}, \mathrm{Mg}^{2+}$, and $\mathrm{K}^{+}$concentrations. There was also a significant positive correlation between $\mathrm{pH}$ and concentrations of $\mathrm{Ca}^{2+}$ and $\mathrm{Na}^{+}$. However, we did not consistently find these correlations to be significant for individual transects $(n=5)$. For the transects where we collected water samples in both 2010 and 2011

\section{HESSD}

9, 14065-14107, 2012

Temporal variation in depth to water table and hydrochemistry

S. A. Howie and

H. J. van Meerveld

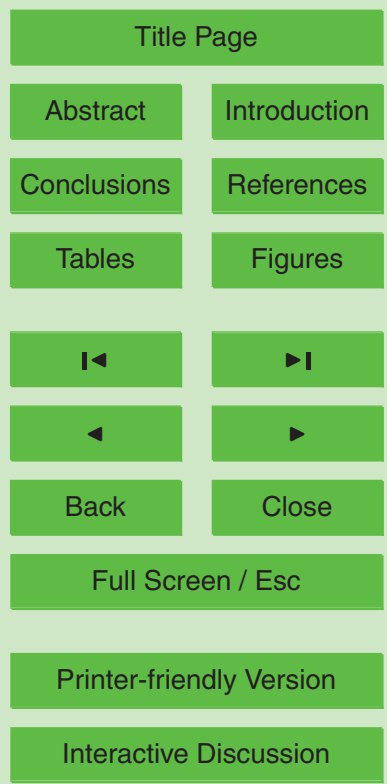


(Sherwood, Cranwest, and Campbell River), we found that the difference in calcium and magnesium concentrations between 2010 and 2011 generally increased across the transects from bog to forest; the other hydrochemical parameters did not display a trend in temporal variability across the transect.

5 In another part of Burns Bog (Pine-salal forest at 100 and $200 \mathrm{~m}$ from edge of bog, Fig. 1), there was also little variation in hydrochemistry during a 1-yr monitoring period from March 2011 to March 2012 (Table 5). From March to August 2011, pH increased, corresponding with the decline in water table over spring and summer, and then decreased between August 2011 and March 2012. However, the maximum change in $10 \mathrm{pH}$ was less than 1, similar to the transects in Burns Bog and Blaney Bog that were monitored in 2010-2011 for this study. Calcium and magnesium concentrations also increased slightly as the water table declined in summer. The relative change in concentration changed from lowest to highest in the following order: $\mathrm{DOC}, \mathrm{SO}_{4}^{2-}, \mathrm{Na}^{+}, \mathrm{K}^{+}$, $\mathrm{Mg}^{2+}, \mathrm{Ca}^{2+}, \mathrm{Cl}^{-}$. Spearman rank correlation tests for these two piezometers revealed 15 a significant positive correlation between depth to water table and: $\mathrm{pH}$ and concentrations of $\mathrm{Ca}^{2+}$ and $\mathrm{Mg}^{2+}$. There was also a significant positive correlation between $\mathrm{pH}$ and $\mathrm{Ca}^{2+}$ and $\mathrm{Mg}^{2+}$ concentrations.

Sodium and chloride are not biologically limiting in oceanic bogs, and consequently accumulate in peat and drainage water (Damman, 1986). In the ombrotrophic "bog" 20 sites on the study transects, concentrations of $\mathrm{Na}^{+}$and $\mathrm{Cl}^{-}$in pore water were, on average, four times higher than in precipitation (Table 6). Nitrogen, phosphorus, and potassium are assumed to be the biologically limiting nutrients in peatlands (Vitt and Chee, 1990; Bridgham et al., 1996); however, our measured $\mathrm{K}^{+}$concentrations were, on average, 29 times higher in pore water than in precipitation in Burns Bog and Campcentrations were, on average, 5 and 9 times higher, respectively, in "bog" pore water than in precipitation (Table 6), so also do not appear to be biologically limiting in this region. The ratio of the average concentration in pore water and precipitation generally increased across the transect from bog to forest for all measured cations and anions,

HESSD

9, 14065-14107, 2012

Temporal variation in depth to water table and hydrochemistry

S. A. Howie and

H. J. van Meerveld

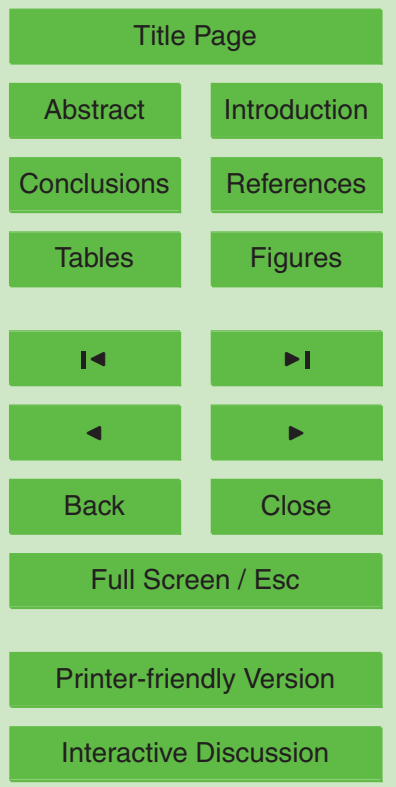


except $\mathrm{K}^{+}$. For example, $\mathrm{Na}^{+}$concentrations in pore water samples were, on average, $4,4,5,7$, and 11 times higher than the average concentration in precipitation for the "bog", "trans1", "trans2", "lagg", and "mineral" sites, respectively. $\mathrm{Ca}^{2+}$ concentrations were, on average, 5, 6, 8, 9, and 16 times higher than the average concentration in 5 precipitation for the "bog", "trans1", "trans2", "lagg", and "mineral" sites, respectively. Sulphate may be the only parameter measured in this study that is biologically limiting; sulphate was generally below the $0.5 \mathrm{mg} \mathrm{L}^{-1}$ detection limit in our water samples, but ranged from $0.7-1.8 \mathrm{mg} \mathrm{L}^{-1}$ in precipitation. Gorham et al. (1985) reported that sulphate concentrations are lower in bogs than in precipitation, particularly in oceanic 10 regions, and attributed this to plant uptake and microbial reduction. Upon entering the peat surface, much of the sulphate from precipitation is reduced to sulphides (Proctor, 1995).

\subsection{Spatial variation in water chemistry}

Spatial differences in $\mathrm{pH}$ across the transects were generally persistent over time for all 15 Burns Bog and Blaney Bog transects, but the pattern varied between the transects. In some cases, $\mathrm{pH}$ consistently increased across the transition from bog to forest (Blaney Bog Upland, Cranwest, DNR) (Fig. 5, Table 3). In other cases, pH fluctuated across the transect without a clear spatial pattern (Sherwood, Blaney Bog Fen). ANOVA results indicate that the difference in $\mathrm{pH}$ across the transects was statistically significant 20 for all transects, except the "fen" transect in Blaney Bog $(p=0.591)$. $\mathrm{EC}_{\text {corr }}$ was generally lowest in the bog and highest towards the lagg and mineral sites, but not in all cases (Fig. 6). Variation in $\mathrm{EC}_{\text {corr }}$ across the transects was statistically significant for all transects, except the "fen" transect in Blaney Bog $(p=0.053)$.

Calcium and magnesium concentrations often increased across the transect from 25 bog to forest, but not in all cases (Table 4). The Ca: Mg ratio did not follow a consistent trend across any transect, and was generally twice as high in Blaney Bog as in Burns Bog, with the exception of the DNR transect (Table 7). Calcium and magnesium

\section{HESSD}

$9,14065-14107,2012$

Temporal variation in depth to water table and hydrochemistry

S. A. Howie and

H. J. van Meerveld

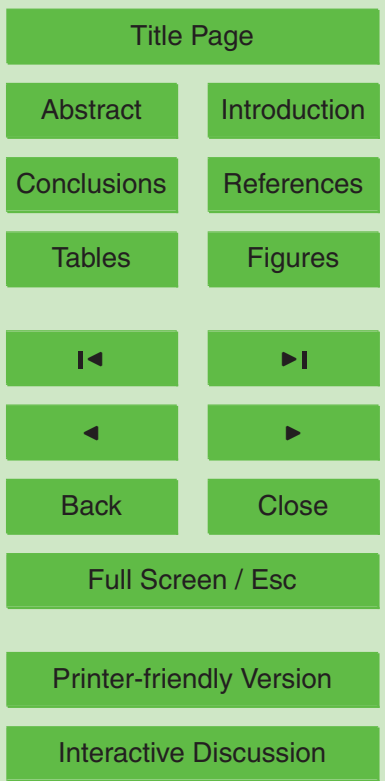


concentrations, and the $\mathrm{Ca}: \mathrm{Mg}$ ratio, were not significantly correlated with position on the transect.

\section{Discussion}

\subsection{Spatial and temporal variation in depth to water table}

5 The water table in bogs often fluctuates in a spatially and temporally consistent manner (Økland et al., 2001). Depth to water table measurements in Burns Bog and Blaney Bog confirm that bogs generally have a smaller annual fluctuation in water table compared to their laggs and adjacent minerotrophic sites (Schouten, 2002; Damman, 1986; Malmer, 1986). On average, the magnitude of the annual fluctuation in depth to water

10 table increased across the transects from bog to lagg and mineral sites in Burns Bog and Blaney Bog (Table 2). The water table in Burns Bog displayed a relatively constant pattern between years, with the winter water table stabilizing at a maximum height between October and March, a gradual decline through spring/summer, and a low point at the end of summer determined by summer precipitation and evapotranspiration (c.f.

15 Golinski, 2004; Howie et al., 2009a; Balfour, 2011). Seasonal water table fluctuations in bogs are closely linked to precipitation (e.g. Malmer, 1986; Dubé et al., 1995). These data suggest that depth to water table measurements during key phases of the hydroperiod (e.g. wet season, spring transition, end of dry season) may be sufficient to obtain a general sense of the annual maximum and minimum depth to water table.

20 The low point of the water table at the end of the dry season is the most critical measurement in ecological terms, because the depth to the water table is closely linked to species composition and Sphagnum survival (Rydin and Jeglum, 2006).

\subsection{Temporal variation in water chemistry}

Observations in Burns Bog and Blaney Bog suggest that although there is some sea25 sonal variability in $\mathrm{pH}$, the variation is relatively low (e.g. generally within $0.5 \mathrm{pH}$ units)

14081

\section{HESSD}

9, 14065-14107, 2012

Temporal variation in depth to water table and hydrochemistry

S. A. Howie and

H. J. van Meerveld

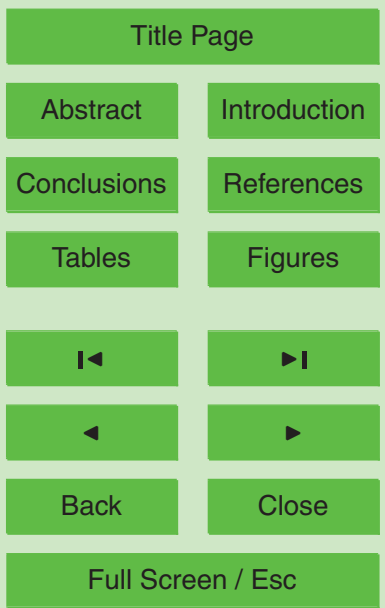

Printer-friendly Version

Interactive Discussion 
and large deviations from the average are not common, so that $\mathrm{pH}$ can be considered as a seasonally stable parameter in the bog, lagg, and mineral locations. Vitt et al. (1995) also found that $\mathrm{pH}$ and $\mathrm{pH}$-corrected electrical conductivity were relatively constant between May and October in Alberta peatlands, and suggested that one-time 5 sampling would be adequate for these parameters. Wieder (1985) found subsurface $\mathrm{pH}$ (at $30 \mathrm{~cm}$ depth) to be relatively constant during the growing season (April-December) in a West Virginia bog. The $\mathrm{pH}$ of deeper bog water may be buffered more from variations in rainfall by ion exchange with the peat (Proctor, 2003; Worrall et al., 2003).

$\mathrm{EC}_{\text {corr }}$ was generally also consistent over time, although it did occasionally spike 10 above the average values. There was no consistent increase or decrease in variability in $\mathrm{EC}_{\text {corr }}$ from bog to forest. The maximum change over time was $88 \mu \mathrm{Scm}^{-1}$. The largest "spike" in $\mathrm{EC}_{\text {corr }}$ (an increase of $66 \mu \mathrm{Scm}^{-1}$, compared to the previous measurement in December 2010) was observed in Burns Bog (DNR transect, "lagg2") in June 2011. There is no clear explanation for this spike, as $\mathrm{EC}_{\text {corr }}$ did not change con15 siderably at the other sites on the transect. Another increase is evident for all sites on the Burns Bog Cranwest transect in September 2011. This increase may have been due to concentration of ions in the peat during dry weather, deposition of dust from the surrounding agricultural fields, or highway construction; $\mathrm{pH}$ was also higher at some sites on this transect on this date (Fig. 5). $\mathrm{EC}_{\text {corr }}$ was also higher in Blaney Bog (up20 land transect, "trans2") in September 2011. EC corr $_{\text {and }} \mathrm{pH}$ both increased across this transect on this date, but it is unclear why $\mathrm{EC}_{\text {corr }}$ at the "trans2" site increased more than at the other sites. Vitt et al. (1995) found only small changes $\left(<50 \mu \mathrm{Scm}^{-1}\right)$ in weekly measurements of corrected conductivity of bog water in central Alberta during the ice-free season.

25 There was also little variation in magnesium and sodium concentrations between the two years. Calcium was more variable at the "trans2" and "mineral" sites of the Cranwest transect, but changed little on the Sherwood transect. The relatively small change in ion concentrations in bog water over time is caused by ion exchange with the peat (Proctor, 2003). Vitt et al. (1995) found that calcium, magnesium, sodium, and
HESSD

9, 14065-14107, 2012

\section{Temporal variation in depth to water table and hydrochemistry}

S. A. Howie and

H. J. van Meerveld

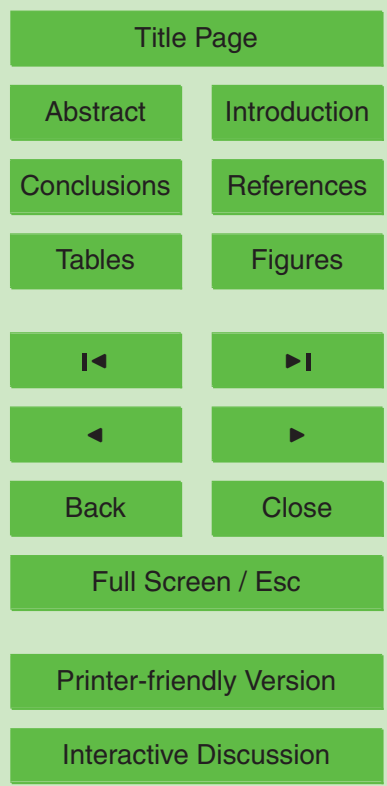


potassium concentrations in an Alberta bog were highest in spring, declined in early summer, and then increased gradually over the summer. However, despite this seasonal pattern, the concentrations of these cations were low $\left(<5 \mathrm{mgL}^{-1}\right)$ throughout the growing season and generally stable. We found a statistically significant correla5 tion between depth to water table and some hydrochemical parameters $\left(\mathrm{EC}_{\mathrm{corr}}, \mathrm{Mg}^{2+}\right.$, $\mathrm{K}^{+}$) but not for the other parameters. Wieder (1985) also found that major cation and chloride concentrations were fairly constant during the growing season. Adamson et al. (2001) found little change $\mathrm{pH}$ and $\mathrm{EC}_{\text {corr }}$ over time, except during drought conditions. The increase during drought periods was attributed to an increase in $\mathrm{H}^{+}$concentration 10 due to evaporative concentration and aerobic conditions, which resulted in oxidation of $\mathrm{H}_{2} \mathrm{SO}_{4}$ to $\mathrm{SO}_{4}^{2-}$ and $\mathrm{H}^{+}$. The increased availability of $\mathrm{H}^{+}$resulted in cation exchange that subsequently increased concentrations of $\mathrm{Na}^{+}, \mathrm{Mg}^{+}$, and $\mathrm{Ca}^{2+}$ (Adamson et al., 2001). Andersen et al. (2010) found relatively small changes in major cation and chloride concentrations over time for a natural peatland in Quebec, compared to restored 5 and unrestored blocks in an adjacent harvested peatland area.

On the other hand, Vitt et al. (1995) found that seasonal variability in calcium and magnesium concentrations was increasingly greater in poor fen, moderately rich fen, and extremely rich fen sites, suggesting that the influence of groundwater determines the variation in cation concentrations over time in fens, whereas soil-water ion concentrations in bog peat are not affected by groundwater and buffered against changes in precipitation chemistry. As a result, pore water chemistry in the bog is generally less variable over time. Similarly, we found that temporal variation of calcium and magnesium concentrations generally increased across the transect from bog to forest. This indicates that a one-time sampling campaign may be adequate for bog sites, but not water. For lagg and mineral sites, samples taken during key hydrological phases (e.g. drought, flooding, heavy rainfall, stable weather conditions) will give a better estimate of the variability in pore water chemistry in response to fluctuations in precipitation and evapotranspiration.

HESSD

9, 14065-14107, 2012

\section{Temporal variation in depth to water table and hydrochemistry}

S. A. Howie and

H. J. van Meerveld

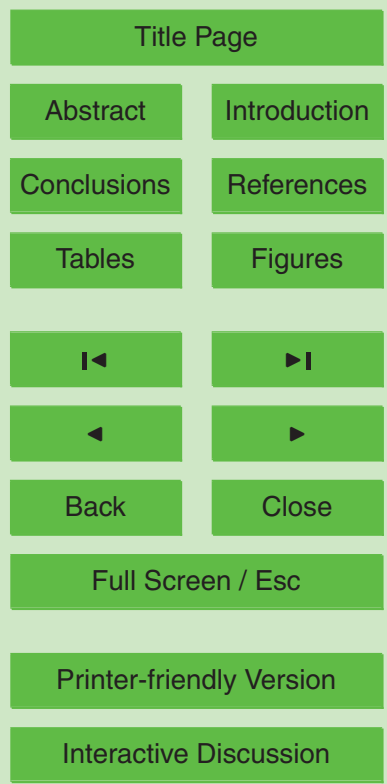


Potassium concentrations differed significantly between June 2010 and June 2011. Proctor (2003) observed that $\mathrm{K}^{+}$concentrations peaked in late spring and declined through the summer, and attributed this trend to depletion by plant uptake during the growing season. Vitt et al. (1995) also suggested that inputs from spring snowmelt and 5 vegetation uptake during the summer accounted for seasonal variation in $\mathrm{K}^{+}$concentrations. A decrease in $\mathrm{K}^{+}$concentrations from 2010 to 2011 was observed at $83 \%$ of the studied sites. The only transect where this trend was not persistent was the Sherwood transect in Burns Bog; two of the sites ("trans1" and "lagg1") showed an increase in $\mathrm{K}^{+}$concentrations between 2010 and 2011 whereas the other sites showed a de10 crease. Chloride concentration displayed similar changes as $\mathrm{K}^{+}$between years, so it is unlikely that the changes in $\mathrm{K}^{+}$concentration between the two years is solely due to differences in plant uptake in 2010 and 2011, but also likely due to precipitation input and evapotranspiration.

Dissolved organic carbon (DOC) concentrations were somewhat stable between 15 years at most sites $\left(<8 \mathrm{mgL}^{-1}\right.$ change), but were more variable at other sites (12$17 \mathrm{mg} \mathrm{L}^{-1}$ change). For Burns Bog, DOC was higher in 2010 than 2011, but in Campbell River DOC was higher in 2011. This may be due to differences in precipitation; at YVR, there was $20 \mathrm{~mm}$ more rainfall in the week prior to sampling in 2010 (possibly causing the higher DOC compared to 2011), and in Campbell River, there was $7 \mathrm{~mm}$ more rainfall in 2011 (possibly causing the marginally higher DOC concentrations in 2011). Adamson et al. (2001) noted that DOC is an indicator of decomposition activity in the soil, and found that DOC correlated with air temperature (lowest concentrations in spring, and highest in late summer and autumn), but that seasonal fluctuations were only significant at $10 \mathrm{~cm}$ below the surface and that fluctuations were smaller at $50 \mathrm{~cm}$ below the surface and did not follow the same seasonal pattern as at $10 \mathrm{~cm}$. Similarly, Fraser et al. (2001) observed a decrease in peatland DOC concentrations with depth, fairly constant DOC concentrations below $75 \mathrm{~cm}$, and larger seasonal fluctuations in the upper $45 \mathrm{~cm}$. They also showed that DOC was lowest $\left(\sim 40 \mathrm{mgL}^{-1}\right)$ during snowmelt, highest ( $\sim 70 \mathrm{mg} \mathrm{L}^{-1}$ ) during the growing season), and increased in response to rainfall
HESSD

9, 14065-14107, 2012

\section{Temporal variation in depth to water table and hydrochemistry}

S. A. Howie and

H. J. van Meerveld

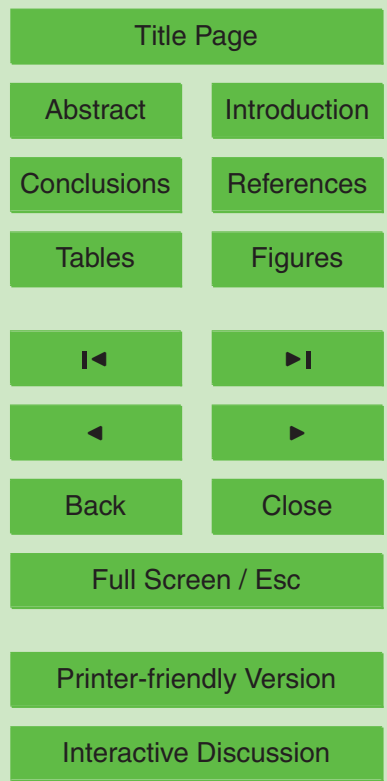


events (Fraser et al. 2001). Since these changes did not correlate with depth to water table, Fraser et al. (2001) attributed the variations in DOC concentrations to substrate availability, temperature, and "DOC partitioning through respiration and methanogenesis". However, air temperatures at YVR and Campbell River in the two weeks prior to 5 sampling did not appear to be correlated with the differences in DOC concentrations between 2010 and 2011; average air temperature was the same in Campbell River in 2010 and 2011, and higher in 2011 at YVR.

\subsection{Spatial variability in water chemistry across the transects}

The only hydrochemical parameters that varied with position on the transect were $\mathrm{pH}$, $10 \mathrm{pH}$-corrected electrical conductivity, and calcium and magnesium concentrations. However, the increase in these hydrochemical parameters from bog to lagg was not consistent. We observed an increase from bog to lagg for $\mathrm{pH}(67 \%$ of the transects) and magnesium ( $83 \%$ of the transects), whereas calcium and $\mathrm{EC}_{\text {corr }}$ only showed this trend for $50 \%$ and $33 \%$ of the transects, respectively. Vitt et al. (1995) found 15 that $\mathrm{pH}, \mathrm{EC}_{\mathrm{corr}}, \mathrm{Ca}^{2+}$, and $\mathrm{Mg}^{2+}$ increased along a bog-rich fen gradient, and were highly correlated with one another. We also found that $\mathrm{Ca}^{2+}$ concentrations were correlated with $\mathrm{pH}$ and $\mathrm{Mg}^{2+}$ concentrations, and that $\mathrm{EC}_{\text {corr }}$ was correlated with $\mathrm{Mg}^{2+}$ and $\mathrm{Ca}^{2+}$ concentrations. Bragazza et al. (2005) observed that $\mathrm{pH}, \mathrm{Ca}^{2+}$, and $\mathrm{Mg}^{2+}$ concentrations in pore water were higher at the mire margin (lagg) than in the mire expanse for an Italian and a Swedish bog. Similarly, Bubier (1991) found higher $\mathrm{Ca}^{2+}$ and $\mathrm{Mg}^{2+}$ concentrations at a lagg stream compared to the bog centre. For the bogs that we studied, the $\mathrm{Ca}: \mathrm{Mg}$ ratio did not appear to be a useful indicator of the mineral soil water limit. Since both $\mathrm{pH}$ and $\mathrm{Mg}^{2+}$ concentrations displayed the most consistent increase across the transects, these parameters may be more useful for locating the mineral soil water limit. However, $\mathrm{pH}$ did not always increase significantly at the transition between bog and lagg, and $\mathrm{Mg}^{2+}$ concentrations were low $\left(<4 \mathrm{mg} \mathrm{L}^{-1}\right)$ so that it may not be a dependable indicator of the location of the lagg or mineral soil water limit.
HESSD

9, 14065-14107, 2012

Temporal variation in depth to water table and hydrochemistry

S. A. Howie and

H. J. van Meerveld

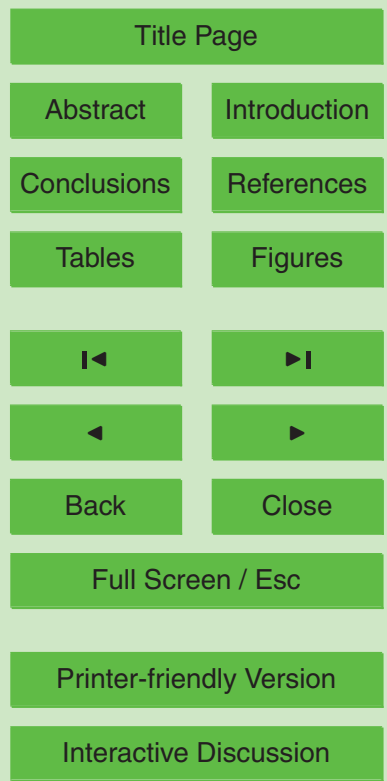


Thus, hydrochemical parameters are not necessarily uniformly useful for determining the location of the mineral soil water limit in coastal BC bogs.

\subsection{Effect of logging}

The unexpected removal of large (10-40 $\mathrm{m}$ tall) trees due to clearcut logging on the 5 Sherwood transect in Burns Bog resulted in a $27 \mathrm{~cm}$ rise in the lowest measured latesummer water table in the clearcut in 2011 compared to the pre-logged condition in 2010, whereas the depth to water table at the other sites was similar in late summer of 2010 and 2011. The mean water table rise in the clearcut between August-November 2010 and 2011 (the period with available data for both years) was $8 \mathrm{~cm}$, compared to a mean water table decline of $13 \mathrm{~cm}$ for the sites on the Sherwood transect that were not affected by the logging. The undisturbed open bog and pine-salal sites on the Sherwood transect (transitional between bog and lagg) showed a mean decrease in water table of $6 \mathrm{~cm}$ and $16 \mathrm{~cm}$, respectively, between August-November 2010 and 2011. The rise in water table in the clearcut site can therefore be attributed to a reduction of interception and evapotranspiration due to the removal of large trees (Dubé et al., 1995). Cheng (2011) observed mean evapotranspiration rates of $0.9 \mathrm{~mm}^{2}$ day $^{-1}$ and $1.1 \mathrm{~mm} \mathrm{day}^{-1}$ in an open bog site and a forested site near the Sherwood transect, respectively, during the 2009 growing season (June-September). However, the area that was logged was dominated by large cedar and hemlock trees (mean DBH: $40 \mathrm{~cm}$ ) rather than small pine trees (mean DBH: $16 \mathrm{~cm}$ in this study, and $15 \mathrm{~cm}$ in Cheng, 2011). The site studied by Cheng contained only two large (mean DBH: $40 \mathrm{~cm}$ ) hemlock trees, but their transpiration rates were 10 times higher than the small pine trees (Cheng, 2011). Differences in evapotranspiration between the clearcut and the lagg forest are thus expected to be larger than the differences in evapotranspiration between in the forested site and negligible in the open bog site due to the lack of trees in the study of Cheng (2011). This would translate to $35 \mathrm{~mm}$ of interception loss between August and November $2011\left(0.3 \mathrm{mmday}^{-1}\right)$, but the large cedar and hemlock trees are 14086

HESSD

9, 14065-14107, 2012

Temporal variation in depth to water table and hydrochemistry

S. A. Howie and

H. J. van Meerveld

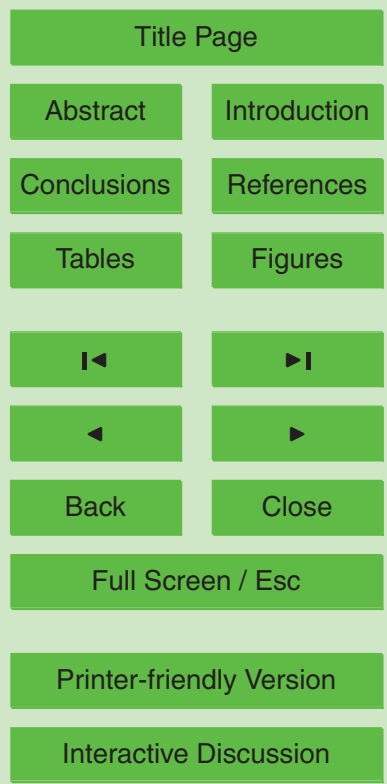


expected to intercept more precipitation than the open pine forest studied by Cheng (2011).

Although the results suggest a significant watering-up effect due to clearcut logging, only one piezometer was located within the clearcut because we were not aware of 5 the logging at the time that this study was initiated. Therefore, it is not possible to confidently state on the basis of this single data point that removal of trees in other areas will result in a similar water table increase. However, our results are similar to (or slightly larger than) those reported for other studies in Canada and Finland (e.g. Dubé et al., 1995; Heikurainen and Päivänen, 1970), which suggests that a water table rise of 10 this order can be expected after tree removal. The watering-up effect in this study is, for example, similar to the mean water table rise of $7 \mathrm{~cm}$, and a maximum rise of $15 \mathrm{~cm}$, for a clearcut black spruce bog in the St. Lawrence lowland (Dubé et al., 1995) and larger than the average watering-up effect of $4 \mathrm{~cm}$ after clearcut logging in a forested wetland near Quebec City (Marcotte et al., 2008). Jutras et al. (2006) found a mean water level rise of $2.6 \mathrm{~cm}$ after pre-commercial thinning of forested wetlands in the St. Lawrence lowland, while Päivänen (1980) observed a water table rise of $6 \mathrm{~cm}$ (when the water table in the control site was $10 \mathrm{~cm}$ below the surface) for clearcut pine and spruce peatland sites in southeast Finland. While removal of large trees can be beneficial for restoring a higher water table in support of the restoration of open bog areas, it may be a detrimental activity in laggs that naturally contain large trees (e.g. Sherwood and DNR laggs). For example, tall trees in the Sherwood lagg forest may benefit the bog by providing a barrier to dust blown from neighbouring farms and roads. In this study, we did not observe a discernible change in $\mathrm{pH}_{\text {or }} \mathrm{EC}_{\text {corr }}$ in response to logging of the lagg forest on the Sherwood transect.

\section{HESSD}

9, 14065-14107, 2012

\section{Temporal variation in depth to water table and hydrochemistry}

S. A. Howie and

H. J. van Meerveld

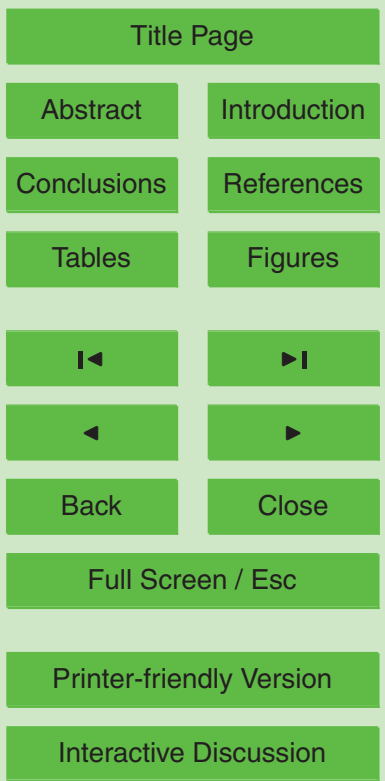




\section{Conclusions}

The wet, temperate climate of coastal British Columbia provides ideal conditions for peatland development so that wetlands cover large areas of the landscape. In order to characterize the hydrological, hydrochemical, and ecological conditions of a represen5 tative sample of peatlands in order to create restoration plans or setting boundaries for conservation areas, it is necessary to characterize their ecohydrological status with relatively few measurements at each site. Annual hydroperiods for coastal $\mathrm{BC}$ bogs display a similar pattern in response to annual cycles of precipitation and evapotranspiration, with water levels dropping further below the bog surface in dry years. We suggest that the hydroperiod can be broadly approximated by taking measurements during key times of the year, such as winter (but not during freezing conditions), spring (May/June), and late summer (August/September). Annual fluctuations of the water table were lowest in the bog sites, and increased toward the lagg and adjacent mineral forest. In the bog, the depth to water table was always less than $40 \mathrm{~cm}$; in the lagg, the depth to water table was always less than $75 \mathrm{~cm}$. These maximum depth to water table values may be used to guide restoration in areas where the lagg has been damaged or lost. Logging on one transect changed the amplitude of the hydroperiod and led to a $27 \mathrm{~cm}$ increase in the lowest measured water level in late summer.

Spatial variation in $\mathrm{EC}_{\text {corr }}$ and $\mathrm{pH}$ across the transects from the bog to mineral sites was statistically significant. Temporal variability in $\mathrm{pH}$ and $\mathrm{EC}_{\text {corr }}$ was, however, not significant. Corrected electrical conductivity, $\mathrm{pH}, \mathrm{Na}^{+}$, and $\mathrm{Mg}^{2+}$ concentrations varied little during the study period and can thus be determined by a one-time sampling campaign. On the other hand, $\mathrm{Ca}^{2+}, \mathrm{K}^{+}, \mathrm{Cl}^{-}$, and dissolved organic carbon concentrations and acidity varied significantly between years and are likely too variable over time to be confidently estimated with a one-time sampling campaign. $\mathrm{Mg}^{2+}$ concentration and $\mathrm{pH}$ increased most frequently from bog to forest, but did not increase consistently at the vegetative transition from bog to lagg.
HESSD

9, 14065-14107, 2012

\section{Temporal variation in depth to water table and hydrochemistry}

S. A. Howie and

H. J. van Meerveld

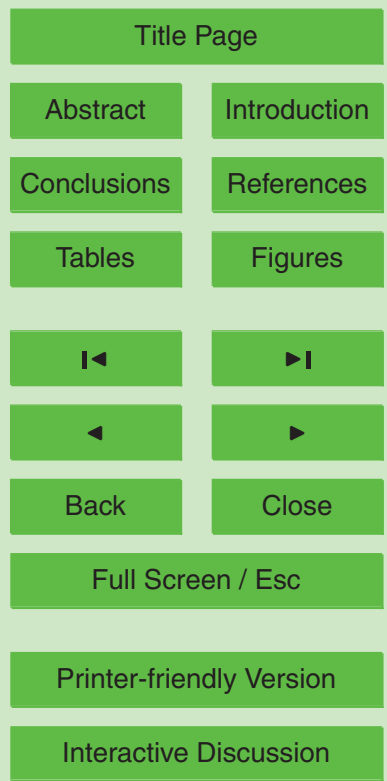


Acknowledgement. Thanks to Metro Vancouver Regional Parks (West Area) for allowing this study to take place in the Burns Bog Ecological Conservancy Area (BBECA), to The Corporation of Delta for allowing research in the Delta Nature Reserve and a Delta-owned property outside the BBECA, to Warren Nottingham for allowing access to the Sherwood Forest lagg, and 5 to Norm Spencer for allowing entry through the Cranwest Farms property to access the lagg south of the farm and for building a ladder over the deer fence. Thanks also to Metro Vancouver Regional Parks (East Area) for granting permission for the study in Blaney Bog. Funding for and analysis of water samples was provided by Environment Canada. Student funding for S.A.H. was provided by Simon Fraser University. Funding for travel was provided by Metro Vancouver

10 Regional Parks. Field equipment for this research was provided by Simon Fraser University, The Corporation of Delta, and Metro Vancouver Regional Parks. Field assistance from Thiago Andrade, Will Howie, Seb Howie, Kate Howie, Jonathan Hughes, Andrew Robinson, Elizabeth Baird, Christina Baird, Angela Danyluk, Erin Riddell, Kim Houghton, Ashley Graham, Jing Niu, Adam Snow, Natasha Murphy, Brad Jones, Stephan Zimmerman, Delta surveyors, Delta co-op

\section{References}

Adamson, J. K., Scott, W.A, Rowland, A. P., and Beard, G. R.: Ionic concentrations in a blanket peat bog in northern England and correlations with deposition and climate variables, Eur. J. Soil Sci., 52, 69-79, 2001.

Andersen, R., Rochefort, L., and Poulin, M.: Peat, water, and plant tissue chemistry monitoring: a seven-year case study in a restored peatland, Wetlands, 30, 159-170, 2010.

Anderson, A. R., Ray, D., and Pyatt, D. G.: Physical and hydrological impacts of blanket bog afforestation at Bad a' Cheo, Caithness: the first 5 years, Forestry, 73, 467-478, 2000.

Balfour, J.: Sixth update report on hydrological monitoring program, Burns Bog, November 2009 to October 2010, MK Delta Lands, Delta, BC, 42 pp., 2011.

Balfour, J. and Banack, L.: Burns Bog Ecosystem Review - Water Chemistry: Report prepared for Delta Fraser Properties Partnership and the Environmental Assessment Office in support of the Burns Bog Ecosystem Review, with additional data collected on publicly owned lands conducted for the Environmental Assessment Office in association with the Corporation of

HESSD

9, 14065-14107, 2012

\section{Temporal variation in depth to water table and hydrochemistry}

S. A. Howie and

H. J. van Meerveld

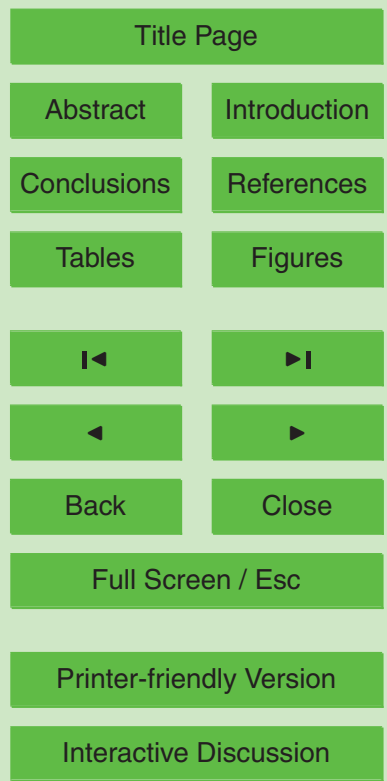


Bragazza, L. and Gerdol, R.: Hydrology, groundwater chemistry and peat chemistry in relation to habitat conditions in a mire on the South-eastern Alps of Italy, Plant Ecol., 144, 243-256, 1999.

Bragazza, L., Rydin, H., and Gerdol, R.: Multiple gradients in mire vegetation: a comparison of a Swedish and an Italian bog, Plant Ecol., 177, 223-236, 2005.

Bragg, O. M.: Hydrology of peat-forming wetlands in Scotland, Sci. Total Environ., 294, 111129, 2002.

Bridgham, S. D., Pastor, J., Janssens, J. A., Chapin, C., and Malterer, T.: Multiple limiting gradients in peatlands: a call for a new paradigm, Wetlands, 16, 45-65, 1996.

10 Bubier, J. L.: Patterns of Picea mariana (Black Spruce) growth and raised bog development in Victory Basin, Vermont, B. Torrey Botan. Club, 118, 399-411, 1991.

Cheng, Y. C.: The ins and outs of Burns Bog: a water balance study, Masters thesis, Simon Fraser University, Burnaby, BC, Canada, https://theses.lib.sfu.ca/thesis/etd6777, 2011.

Damman, A. W. H.: Hydrology, development, and biogeochemistry of ombrogenous peat bogs 15 with special reference to nutrient relocation in a western Newfoundland bog, Can. J. Bot., 64, 384-394, 1986.

Damman, A. W. H. and French, T. W.: The ecology of peat bogs of the glaciated northwestern United States: a community profile, US Fish and Wildlife Service Biological Report 85, 1987.

Dubé, S., Plamondon, A. P., and Rothwell, R. L.: Watering up after clear-cutting on forested wetlands of the St. Lawrence lowland, Water Resour. Res., 31, 1741-1750, 1995.

Egglesmann, R., Heathwaite, A. L., Grosse-Brauckmann, G., Kuster, E., Naucke, W., Schuch, M., and Schweickle, V.: Physical processes and properties of mires, in: Mires: Process, Exploitation and Conservation, edited by: Heathwaite, A. L. and Göttlich, Kh., John Wiley \& Sons Ltd., Chichester, 171-262, 1993.

Environment Canada, National Climate Data and Information Archive: http://www.climate. weatheroffice.gc.ca/climateData/canada_e.html, last access: 25 July 2012.

Fay, E. and Lavoie, C.: The impact of birch seedlings on evapotranspiration from a mined peatland: an experimental study in southern Quebec, Canada, Mires Peat, 5, 1-7, 2009.

Fraser, C. J. D., Roulet, N. T., and Moore, T. R.: Hydrology and dissolved organic carbon biogeochemistry in an ombrotrophic bog, Hydrol. Process., 15, 3151-3166, 2001.

Gebauer, M. B.: Blaney Bog and adjacent uplands: summary of existing biophysical information, Prepared for Greater Vancouver Regional District, Burnaby, BC, 2002.
HESSD

9, 14065-14107, 2012

Temporal variation in depth to water table and hydrochemistry

S. A. Howie and

H. J. van Meerveld

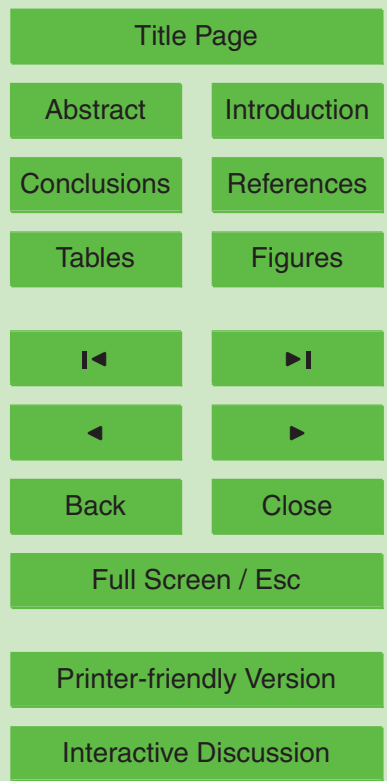


Glaser, P. H., Janssens, J. A., and Siegel, D. I.: The response of vegetation to chemical and hydrological gradients in the Lost River peatland, northern Minnesota, J. Ecol., 78, 10211048, 1990.

Golinski, G. K.: Mires of Vancouver Island, British Columbia: vegetation classification and differences between disturbed and undisturbed mires, PhD thesis, University of Victoria, Victoria, BC, 2004.

Gorham, E., Eisenreich, S. J., Ford, J., and Santelmann, M. V.: The chemistry of bog waters, in: Chemical Processes in Lakes, edited by: Stumm, W., Wiley, New York, 339-363, 1985.

Heikurainen, L. and Päivänen, J.: The effect of thinning, clear cutting and fertilization on the hydrology of peatland drained for forestry, Acta For. Fenn., 104, 22 pp., 1970.

Hobbs, N. B.: Mire morphology and the properties and behaviour of some British and foreign peats, Quarterly J. Engin. Geol., 19, 7-80, 1986.

Holden, J., Chapman, P. J., and Labadz, J. C.: Artificial drainage of peatlands: hydrological and hydrochemical process and wetland restoration, Progress Phys. Geogr., 28, 95-123, 2004.

Holden, J.: Peatland hydrology and carbon release: why small-scale process matters, Philos. T. Roy. Soc. A, 363, 2891-2913, 2005.

Howie, S. A. and Tromp-van Meerveld, I.: The essential role of the lagg in raised bog function and restoration: a review, Wetlands, 31, 613-622, 2011.

Howie, S. A., Whitfield, P. H., Hebda, R. J., Munson, T. G., Dakin, R. A., and Jeglum, J. K.: Water table and vegetation response to ditch blocking: restoration of a raised bog in southwestern British Columbia, Can. Water Resour. J., 34, 381-392, 2009a.

Howie, S. A., Whitfield, P. H., Hebda, R. J., Dakin, R. A., and Jeglum, J. K.: Can analysis of historic lagg forms be of use in the restoration of highly altered raised bogs? Examples from Burns Bog, British Columbia, Can. Water Resour. J., 34, 427-440, 2009b.

Jeglum, J. K., Kershaw, H. M., Morris, D. M., and Cameron, D. A.: Best forestry practices: a guide for the boreal forest in Ontario, Canadian Forest Service, Great Lakes Forestry Centre, Sault Ste. Marie, Ontario, 110 pp., 2003.

Jutras, S., Plamondon, A. P., Hökkä, H., and Bégin, J.: Water table changes following precommercial thinning on post-harvest drained wetlands, Forest Ecol. Manage., 235, 252-259, 302006.

Lähteenoja, O., Ruokolainen, K., Schulman, L., and Alvarez, J.: Amazonian floodplains harbour minerotrophic and ombrotrophic peatlands, Catena, 79, 140-145, 2009.
HESSD

$9,14065-14107,2012$

Temporal variation in depth to water table and hydrochemistry

S. A. Howie and

H. J. van Meerveld

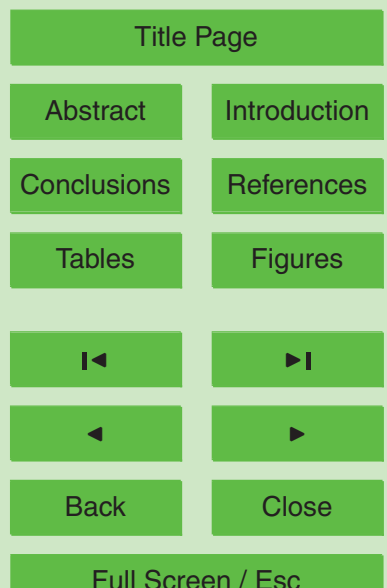

Full Screen / Esc

Printer-friendly Version

Interactive Discussion 
Lavoie, C., Grosvernier, P., Girard, M., and Marcoux, K.: Spontaneous revegetation of mined peatlands: an useful restoration tool?, Wetlands Ecol. Manage., 11, 97-107, 2003.

Malmer, N.: Vegetational gradients in relation to environmental conditions in northwestern European mires, Can. J. Bot., 64, 375-383, 1986.

5 Marcotte, P., Roy, V., Plamondon, A. P., and Auger, I.: Ten-year water table recovery after clearcutting and draining boreal forested wetlands of eastern Canada, Hydrol. Process., 22, 4163-4172, 2008.

National Atmospheric Chemistry Database, http://www.on.ec.gc.ca/NatChem/Login/Login. aspx, last access: 15 October 2012.

10 National Wetlands Working Group (NWWG): Wetlands of Canada, Environment Canada, Ecological Land Classification Series, No. 24, 1988.

Naucke, W., Heathwaite, A. L., Egglesmann, R., and Schuch, M.: Mire chemistry, in: Mires: Process, Exploitation and Conservation, edited by: Heathwaite, A. L. and Göttlich, Kh., John Wiley \& Sons Ltd., Chichester, 263-310, 1993.

Nelson, M. L., Rhoades, C. C., and Dwire, K. A.: Influence of bedrock geology on water chemistry of slope wetlands and headwater streams in the southern Rocky Mountains, Wetlands, 31, 251-261, 2011.

Økland, R. H., Økland, T., and Rydgren, K.: A Scandinavian perspective on ecological gradients in north-west European mires: reply to Wheeler and Proctor, J. Ecol., 89, 481-486, 2001.

20 Päivänen, J.: The effect of silvicultural treatments on the ground water table in Norway spruce and Scots pine stands on peat, in: Proceedings of the 6th International Peat Congress, Duluth, MN, USA, 1980.

Päivänen, J. and Hånell, B.: Peatland ecology and forestry - a sound approach, University of Helsinki, Department of Forest Sciences Publications, 3, 267 pp., 2012.

Piteau Associates: Hydrological Assessment of Burns Bog, Delta, British Columbia, Report prepared for the BC Ministry of Environment, Lands and Parks, North Vancouver, BC, 54 pp., 1994.

Price, J. S., Heathwaite, A. L., and Baird, A. J.: Hydrological processes in abandoned and restored peatlands: an overview of management approaches, Wetlands Ecol. Manage., 11, $30 \quad 65-83,2003$.

Proctor, M. C. F.: Seasonal and shorter-term changes in surface-water chemistry on four English ombrogenous bogs, J. Ecol., 82, 597-610, 1994.

HESSD

9, 14065-14107, 2012

Temporal variation in depth to water table and hydrochemistry

S. A. Howie and H. J. van Meerveld

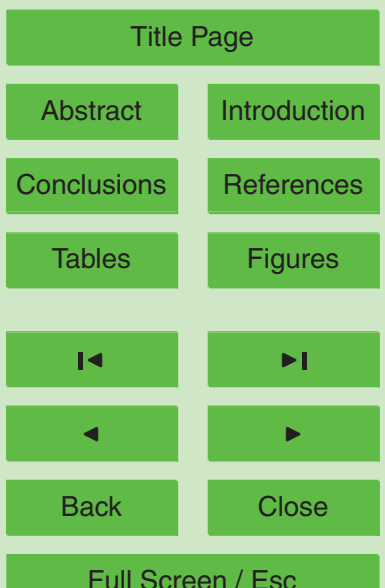

Full Screen / Esc

Printer-friendly Version

Interactive Discussion 
Proctor, M. C. F.: The ombrogenous bog environment, in: Restoration of Temperate Wetlands, edited by: Wheeler, B. D., Shaw, S. C., Fojt, W. J., and Robertson, R. A., John Wiley \& Sons Ltd., Chichester, 287-304, 1995.

Proctor, M. C. F.: Malham Tarn Moss: the surface-water chemistry of an ombrotrophic bog, Field Stud., 10, 553-578, 2003.

Roy, V., Jeglum, J. K., and Plamondon, A. P.: Water table fluctuations following clearcutting and thinning on Wally Creek wetlands, in: Northern Forested Wetlands: Ecology and Management, edited by: Trettin, C. C., Jurgensen, M. F., Grigal, D. F., Gale, M. R., and Jeglum, J. K., Lewis Publishers, CRC Press, Boca Raton, FL, 239-251, 1997.

10 Roy, V., Plamondon, A. P., and Bernier, P.: Influence of vegetation removal and regrowth on interception and water table level on wetlands, Int. Peat J. 10, 3-12, 2000.

Rydin, H. and Jeglum, J.: The Biology of Peatlands, Oxford University Press, New York, 2006.

Schouten, M. G. C. (Ed.): Conservation and Restoration of Raised Bogs: Geological, Hydrological and Ecological Studies, Department of Environment and Local Government, Dublin, 2002.

Schouwenaars, J. M. and Vink, J. P. M.: Hydrophysical properties of peat relicts in a former bog and perspectives for Sphagnum regrowth, Int. Peat J., 4, 15-28, 1992.

Shotyk, W.: Peat bog archives of atmospheric metal deposition: geochemical evaluation of peat profiles, natural variations in metal concentrations, and metal enrichment factors, Environ. 20 Rev., 4, 149-183, 1996.

Sjörs, H. and Gunnarsson, U.: Calcium and $\mathrm{pH}$ in north and central Swedish mire waters, J. Ecol., 90, 650-657, 2002.

Tahvanainen, T., Sallantaus, T., Heikkila, R., and Tolonen, K.: Spatial variation of mire surface water chemistry and vegetation in northeastern Finland, Ann. Bot. Fennici., 39, 235-251, 2002.

Vitt, D. H. and Chee, W.: The relationships of vegetation to surface water chemistry and peat chemistry in fens of Alberta, Canada, Vegetatio, 89, 87-106, 1990.

Vitt, D. H., Bayley, S. E., and Jin, T.: Seasonal variation in water chemistry over a bog-rich fen gradient in Continental Western Canada, Can. J. Fish. Aquat. Sci., 52, 587-606, 1995.

30 Waughman, G. J.: Chemical aspects of the ecology of some south German peatlands, J. Ecol., 68, 1025-1046, 1980.

Wheeler, B. D. and Shaw, S. C.: Restoration of damaged peatlands with particular reference to lowland raised bogs affected by peat extraction, HMSO, London, 211 pp., 1995.

HESSD

9, 14065-14107, 2012

Temporal variation in depth to water table and hydrochemistry

S. A. Howie and H. J. van Meerveld

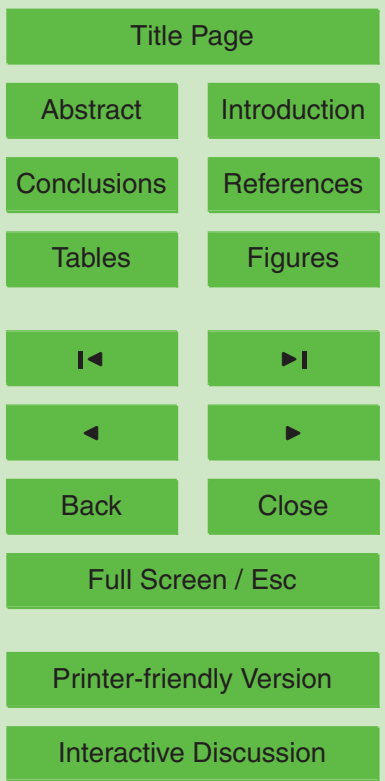


Wheeler, B. D., Shaw, S. C., Fojt, W. J., and Robertson, R. A.: Restoration of Temperate Wetlands, John Wiley \& Sons Ltd., New York, 1995.

Wieder, R. K.: Peat and water chemistry at Big Run Bog, a peatland in the Appalachian mountains of West Virginia, USA, Biogeochemistry, 1, 277-302, 1985.

5 Worrall, F., Burt, T., and Adamson, J.: Controls on the chemistry of runoff from an upland peat catchment, Hydrol. Process., 17, 2063-2083, 2003.

\section{HESSD}

9, 14065-14107, 2012

Temporal variation in depth to water table and hydrochemistry

S. A. Howie and

H. J. van Meerveld

Title Page

Abstract

Introduction

Conclusions

References

Tables

Figures

14

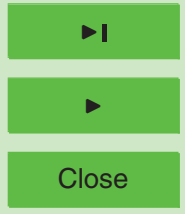

Back

Full Screen / Esc

Printer-friendly Version

Interactive Discussion 


\section{HESSD}

9, 14065-14107, 2012

\section{Temporal variation in depth to water table and hydrochemistry}

Table 1. Coordinates of the transects ("bog" sampling point) and sampling dates.

\begin{tabular}{|c|c|c|c|c|c|c|}
\hline Transect location & Latitude & Longitude & $\begin{array}{l}\text { Transect } \\
\text { length }(m)\end{array}$ & $\begin{array}{l}\text { Maximum } \\
\text { elevation } \\
\text { difference on } \\
\text { transect }(\mathrm{m})\end{array}$ & $\begin{array}{l}\text { Frequency of water } \\
\text { level and } \mathrm{EC} / \mathrm{pH} \\
\text { measurements } \\
\text { ( } n=\text { total number of } \\
\mathrm{EC} / \mathrm{pH} \text { measurements) }\end{array}$ & $\begin{array}{l}\text { Collection } \\
\text { dates for water } \\
\text { chemistry } \\
\text { samples }\end{array}$ \\
\hline Burns Bog - Sherwood & $49^{\circ} 6^{\prime} 26^{\prime \prime} \mathrm{N}$ & $123^{\circ} 1^{\prime} 10^{\prime \prime} \mathrm{W}$ & 560 & 2.9 & $\begin{array}{l}1-3 \text { months* } \\
(n=9)\end{array}$ & $\begin{array}{l}6 \text { Jun } 2010 ; \\
21 \text { Jun } 2011\end{array}$ \\
\hline Burns Bog - Cranwest & $49^{\circ} 7^{\prime} 26^{\prime \prime} \mathrm{N}$ & $123^{\circ} 0^{\prime} 36^{\prime \prime} \mathrm{W}$ & 830 & 1.6 & $\begin{array}{l}1-3 \text { months } \\
(n=9)\end{array}$ & $\begin{array}{l}6 \text { \& } 10 \text { Jun } 2010 ; \\
20 \text { Jun } 2011\end{array}$ \\
\hline Burns Bog - DNR & $49^{\circ} 8^{\prime} 16^{\prime \prime} \mathrm{N}$ & $122^{\circ} 56^{\prime} 11^{\prime \prime} \mathrm{W}$ & 1000 & 1.4 & $\begin{array}{l}\text { 4-6 months } \\
(n=4)\end{array}$ & 18 Jun 2011 \\
\hline Blaney Bog - Upland & $49^{\circ} 15^{\prime} 35^{\prime \prime} \mathrm{N}$ & $122^{\circ} 35^{\prime} 18^{\prime \prime} \mathrm{W}$ & 180 & 1.3 & $\begin{array}{l}3 \text { months } \\
(n=5)\end{array}$ & 25 Jun 2011 \\
\hline Blaney Bog - Fen & $49^{\circ} 15^{\prime} 33^{\prime \prime} \mathrm{N}$ & $122^{\circ} 35^{\prime} 24^{\prime \prime} \mathrm{W}$ & 100 & 1.5 & $\begin{array}{l}3 \text { months } \\
(n=5)\end{array}$ & 25 Jun 2011 \\
\hline Campbell River Bog & $49^{\circ} 57^{\prime} 60^{\prime \prime} \mathrm{N}$ & $125^{\circ} 14^{\prime} 34^{\prime \prime} \mathrm{W}$ & 100 & 1.5 & $\begin{array}{l}\text { Annually }(2010 / 2011) \\
(n=2)\end{array}$ & $\begin{array}{l}24 \text { May 2010; } \\
31 \text { May } 2011\end{array}$ \\
\hline
\end{tabular}

* Depth to water table measurement frequency at this site increased to weekly between August and December 2011, and then returned to monthly until December 2012.

S. A. Howie and

H. J. van Meerveld

Title Page

Abstract

Introduction

Conclusions

References

Tables

Figures

14

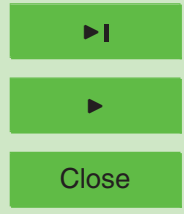

Back

Full Screen / Esc

Printer-friendly Version

Interactive Discussion 


\section{HESSD}

9, 14065-14107, 2012

Temporal variation in depth to water table and hydrochemistry

Table 2. Difference $(\Delta)$ between the maximum and minimum depth to water table for all sites.

\begin{tabular}{lcccccc}
\hline & \multicolumn{6}{c}{$\Delta$ water table depth below surface $(\mathrm{m})$} \\
& "bog" & "trans1" & "trans2" & "lagg1" & "lagg2" & "mineral" \\
\hline Burns Bog - Sherwood & 0.31 & 0.54 & 0.52 & 0.46 & 0.59 & 0.74 \\
Burns Bog - Cranwest & 0.42 & 0.36 & 0.66 & 0.61 & - & 0.47 \\
Burns Bog - DNR & 0.32 & - & - & 0.72 & 0.45 & 0.64 \\
Blaney Bog - Upland & 0.26 & 0.33 & 0.41 & 0.63 & - & 0.79 \\
Blaney Bog - Fen & 0.34 & 0.38 & 0.40 & 0.51 & - & 0.41 \\
MEAN & 0.33 & 0.40 & 0.50 & 0.59 & 0.52 & 0.61 \\
MEDIAN & 0.32 & 0.37 & 0.47 & 0.61 & 0.52 & 0.64 \\
STD. DEV. & 0.05 & 0.07 & 0.09 & 0.08 & 0.06 & 0.14 \\
\hline
\end{tabular}

S. A. Howie and

H. J. van Meerveld

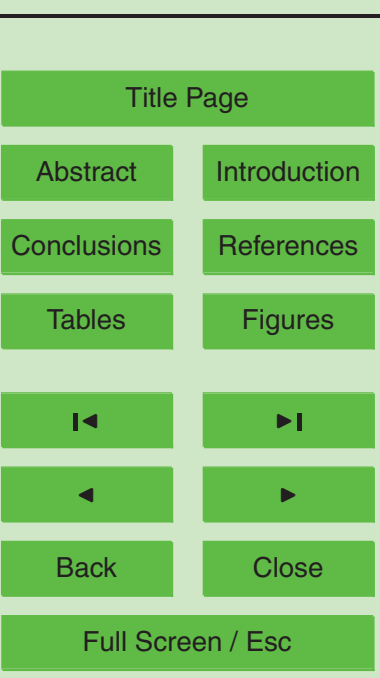

Printer-friendly Version

Interactive Discussion 


\section{HESSD}

9, 14065-14107, 2012

\section{Temporal variation in depth to water table and hydrochemistry}

Table 3. Range in $\mathrm{pH}$ for all sites (May 2010-December 2011). See Table 1 for the frequency of the measurements.

\begin{tabular}{lcccccc}
\hline & \multicolumn{7}{c}{$\mathrm{pH}$ range (minimum-maximum) } & \\
& "bog" & "trans1" & "trans2" & "lagg1" & "lagg2" & "mineral" \\
\hline Burns Bog - Sherwood & $3.71-4.30$ & $3.84-3.95$ & $3.76-4.00$ & $4.04-4.38$ & $3.56-3.86$ & $3.64-4.24$ \\
Burns Bog - Cranwest & $3.88-4.22$ & $4.32-4.51$ & $3.90-4.75$ & $4.13-4.94$ & - & $5.10-5.41$ \\
Burns Bog - DNR & $4.09-4.36$ & - & - & $4.17-4.57$ & $5.20-5.39$ & $5.51-5.72$ \\
Blaney Bog - Upland & $4.09-4.42$ & $4.21-4.37$ & $4.34-4.90$ & $4.95-5.36$ & - & $5.19-5.84$ \\
Blaney Bog - Fen & $4.28-4.69$ & $4.25-4.53$ & $4.30-4.66$ & $4.22-4.67$ & - & $4.35-4.57$ \\
Campbell River Bog & $4.23^{*}$ & $4.25-4.67$ & $4.52^{*}$ & $6.08-6.29$ & - & $6.49-6.68$ \\
MEAN & 4.10 & 4.24 & 4.31 & 4.60 & 4.32 & 4.98 \\
MEDIAN & 4.09 & 4.30 & 4.33 & 4.43 & 3.82 & 5.19 \\
STD. DEV. & 0.27 & 0.24 & 0.36 & 0.54 & 0.83 & 0.79 \\
\hline
\end{tabular}

* Measurements from May 2011 (May 2010 measurements are not included due to incomplete piezometer development).

S. A. Howie and

H. J. van Meerveld

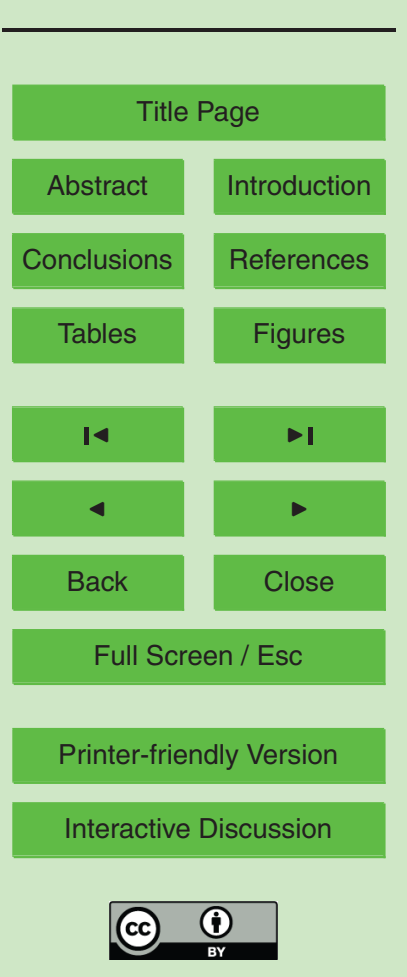




\section{HESSD}

Table 4. Pore water concentrations for Burns Bog, Blaney Bog, and Campbell River Bog in May/June 2010 and May/June 2011. SW =Sherwood, DNR=Delta Nature Reserve, $\mathrm{CW}=$ Cranwest, $\mathrm{BU}=$ Blaney Bog Upland, $\mathrm{BF}=$ Blaney Bog Fen, $\mathrm{CR}=$ Campbell River Bog. Dates and locations for which water samples were not collected are indicated by “-".

\begin{tabular}{|c|c|c|c|c|c|c|c|c|c|c|c|c|c|c|c|c|c|}
\hline & \multirow[t]{2}{*}{$\begin{array}{l}\text { Sample } \\
\text { location }\end{array}$} & \multicolumn{2}{|c|}{$\mathrm{Ca}^{2+}\left(\mathrm{mg} \mathrm{L}^{-1}\right)$} & \multicolumn{2}{|c|}{$\mathrm{Mg}^{2+}\left(\mathrm{mg} \mathrm{L}^{-1}\right)$} & \multicolumn{2}{|c|}{$\mathrm{Na}^{+}\left(\mathrm{mg} \mathrm{L}^{-1}\right)$} & \multicolumn{2}{|c|}{$\mathrm{K}^{+}\left(\mathrm{mg} \mathrm{L}^{-1}\right)$} & \multicolumn{2}{|c|}{$\mathrm{SO}_{4}^{2-}\left(\mathrm{mg} \mathrm{L}^{-1}\right)$} & \multicolumn{2}{|c|}{$\mathrm{Cl}^{-}\left(\mathrm{mg} \mathrm{L}^{-1}\right)$} & \multicolumn{2}{|c|}{$\begin{array}{c}\text { Acidity } \\
\left(\mathrm{mg} \mathrm{CaCO}_{3} \mathrm{~L}^{-1}\right)\end{array}$} & \multicolumn{2}{|c|}{$\mathrm{DOC}\left(\mathrm{mg} \mathrm{L}^{-1}\right)$} \\
\hline & & 2010 & 2011 & 2010 & 2011 & 2010 & 2011 & 2010 & 2011 & 2010 & 2011 & 2010 & 2011 & 2010 & 2011 & 2010 & 2011 \\
\hline \multirow{15}{*}{$\begin{array}{l}\text { D } \\
\infty \\
0 \\
\sum^{2} \\
0 \\
0\end{array}$} & SW "Bog" & 1.3 & 1.4 & 1.0 & 1.0 & 3.4 & 4.3 & 7.6 & 4.6 & $<0.5$ & $<0.5$ & 9.8 & 4.8 & 33 & 46 & 71.6 & 65.7 \\
\hline & SW "Trans1" & 1.1 & 1.1 & 1.6 & 1.5 & 2.7 & 2.7 & 5.2 & 20.0 & 0.8 & $<0.5$ & 10.0 & 17.0 & 26 & 53 & 57.4 & 58.3 \\
\hline & SW “Trans2" & 1.5 & 1.1 & 1.5 & 1.5 & 2.8 & 2.4 & 10.5 & 6.0 & $<0.5$ & $<0.5$ & 9.0 & 8.5 & 29 & 39 & 71.0 & 54.4 \\
\hline & SW “Lagg1” & 2.5 & 1.9 & 1.6 & 1.7 & 1.9 & 2.0 & 2.4 & 15.9 & 0.6 & $<0.5$ & 7.9 & 16.0 & 18 & 34 & 64.8 & 61.1 \\
\hline & SW "Lagg2" & 2.4 & - & 1.8 & - & 4.1 & - & 5.1 & - & 2.9 & - & 10.8 & - & 59 & - & 100.0 & 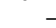 \\
\hline & SW "Mineral" & 5.9 & 4.9 & 4.0 & 3.9 & 5.7 & 5.4 & 7.0 & 2.6 & 5.2 & 1.6 & 22.0 & 15.0 & 33 & 52 & 95.2 & 90.8 \\
\hline & DNR "Bog" & - & - & - & - & - & - & - & - & - & - & - & - & - & - & - & - \\
\hline & DNR "Lagg1" & - & 3.8 & - & 0.7 & - & 5.5 & - & 5.3 & - & $<0.5$ & - & 9.4 & - & 34 & - & 84.0 \\
\hline & DNR “Lagg2” & - & 2.6 & - & 0.8 & - & 16.6 & - & 8.3 & - & $<0.5$ & - & 19.0 & - & 46 & - & 79.5 \\
\hline & DNR "Mineral" & - & 9.4 & - & 3.1 & - & 10.4 & - & 3.4 & - & $<0.5$ & - & 11.2 & - & 21 & & 65.3 \\
\hline & CW "Bog" & 1.5 & 2.1 & 1.1 & 1.1 & 5.1 & 4.6 & 4.5 & 3.0 & $<0.5$ & $<0.5$ & 8.4 & 5.4 & 24 & 54 & 84.5 & 77.4 \\
\hline & CW “Trans1" & 2.1 & 1.5 & 1.0 & 1.0 & 5.7 & 5.7 & 1.5 & 1.1 & $<0.5$ & $<0.5$ & 11.5 & 9.4 & 13 & 47 & 63.9 & 60.3 \\
\hline & CW “Trans2" & 3.4 & 1.8 & 1.6 & 0.9 & 3.2 & 2.8 & 6.8 & 2.2 & 1.9 & $<0.5$ & 9.1 & 3.7 & 24 & 31 & 81.8 & 69.5 \\
\hline & CW "Lagg" & - & 1.8 & - & 0.9 & - & 2.5 & - & 4.8 & - & $<0.5$ & - & 3.7 & - & 27 & - & 59.8 \\
\hline & CW "Mineral" & 5.0 & 3.1 & 1.2 & 1.7 & 16.7 & 17.6 & 7.2 & 6.4 & - & - & - & - & - & - & - & 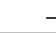 \\
\hline \multirow{10}{*}{ 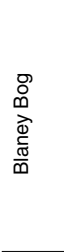 } & BU - "Bog" & - & 0.5 & - & $<0.1$ & - & 0.8 & - & 0.7 & - & $<0.5$ & - & 2.6 & - & 33 & - & 37.1 \\
\hline & BU - "Trans1" & - & 0.3 & - & $<0.1$ & - & 1.5 & - & 0.5 & - & $<0.5$ & - & 2.7 & - & 37 & - & 52.5 \\
\hline & BU - "Trans2" & - & 0.9 & - & 0.1 & - & 6.0 & - & 1.2 & - & $<0.5$ & - & 4.4 & - & 45 & - & 123.0 \\
\hline & BU - "Lagg" & - & 3.2 & - & 0.5 & - & 1.7 & - & 0.6 & - & $<0.5$ & - & 2.6 & - & 19 & - & 33.4 \\
\hline & BU - "Mineral" & - & 4.7 & - & 0.7 & - & 3.6 & - & 0.8 & - & 0.7 & - & 3.3 & - & 13 & - & 23.8 \\
\hline & BF - "Bog" & - & 1.2 & - & 0.3 & - & 0.9 & - & 0.7 & - & $<0.5$ & - & 2.2 & - & 36 & - & 42.6 \\
\hline & BF - "Trans1" & - & 2.0 & - & 0.8 & - & 0.8 & - & 0.8 & - & $<0.5$ & - & 2.2 & - & 38 & - & 41.5 \\
\hline & BF - "Trans2" & - & 2.5 & - & 0.6 & - & 0.8 & - & 0.9 & - & $<0.5$ & - & 2.6 & - & 23 & - & 48.3 \\
\hline & BF - "Lagg" & - & 1.3 & - & 0.2 & - & 0.9 & - & 0.9 & - & $<0.5$ & - & 2.7 & - & 21 & - & 37.6 \\
\hline & BF - "Mineral" & - & 2.0 & - & 0.7 & - & 2.3 & - & 0.7 & - & $<0.5$ & - & 5.0 & - & 41 & - & 61.1 \\
\hline \multirow{5}{*}{ 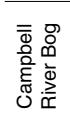 } & CR "Bog" & - & 1.7 & - & 0.7 & - & 4.8 & - & 2.1 & - & $<0.5$ & - & 10.0 & - & 23 & - & 55.8 \\
\hline & CR "Trans1" & 3.6 & 2.5 & 1.0 & 1.0 & 5.3 & 4.8 & 4.9 & 0.6 & $<0.5$ & $<0.5$ & 12 & 8.1 & 18 & 28 & 50.5 & 51.6 \\
\hline & CR "Trans2" & - & 3.6 & - & 1.1 & - & 4.6 & - & 1.4 & - & $<0.5$ & - & 6.8 & - & 30 & - & 81.2 \\
\hline & CR “Lagg” & 5.1 & 4.0 & 1.7 & 1.5 & 6.1 & 6.2 & 5.6 & 1.1 & $<0.5$ & $<0.5$ & 10 & 9.3 & 12 & 11 & 21.6 & 28.3 \\
\hline & CR "Mineral" & 6.7 & 2.5 & 1.4 & 1.0 & 5.7 & 5.5 & 9.6 & 1.1 & - & $<0.5$ & - & 8.3 & - & 13 & - & 11.9 \\
\hline
\end{tabular}

Temporal variation in depth to water table and hydrochemistry

S. A. Howie and H. J. van Meerveld

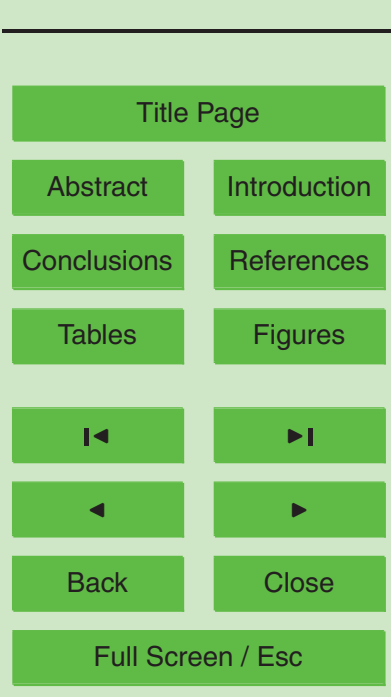

Printer-friendly Version

Interactive Discussion

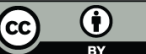




\section{HESSD}

\section{9, 14065-14107, 2012}

\section{Temporal variation in depth to water table \\ and hydrochemistry}

Table 5. Data from two piezometers (PF-100 and PF-200) in Burns Bog (see Fig. 1 for location of these piezometers). DTW = depth to water table; $\mathrm{EC}_{\text {corr }}=$ corrected electrical conductivity; $\mathrm{DOC}=$ dissolved organic carbon.

\begin{tabular}{|c|c|c|c|c|c|c|c|c|}
\hline \multirow{2}{*}{ Parameter } & \multicolumn{2}{|c|}{8 Mar 2011} & \multicolumn{2}{|c|}{28 Jun 2011} & \multicolumn{2}{|c|}{29 Aug 2011} & \multicolumn{2}{|c|}{21 Mar 2012} \\
\hline & PF-100 & PF-200 & PF-100 & PF-200 & PF-100 & PF-200 & PF-100 & PF-200 \\
\hline DTW (m) & 0.41 & 0.41 & 0.58 & 0.57 & 0.89 & 0.84 & 0.36 & 0.33 \\
\hline $\mathrm{pH}$ & 3.79 & 3.85 & 4.27 & 4.15 & 4.62 & 4.45 & 3.73 & 3.71 \\
\hline $\mathrm{EC}_{\mathrm{corr}}\left(\mu \mathrm{S} \mathrm{cm}^{-1}\right)$ & 61 & 52 & 45 & 44 & 70 & 55 & 47 & 35 \\
\hline $\mathrm{Ca}^{2+}\left(\mathrm{mg} \mathrm{L}^{-1}\right)$ & 0.9 & 0.8 & 1.6 & 1.5 & 2.9 & 2.6 & 1.1 & 1.3 \\
\hline $\mathrm{Mg}^{2+}\left(\mathrm{mg} \mathrm{L}^{-1}\right)$ & 0.7 & 0.8 & 0.9 & 1.1 & 1.8 & 1.8 & 0.6 & 0.7 \\
\hline $\mathrm{Na}^{+}\left(\mathrm{mg} \mathrm{L}^{-1}\right)$ & 2.1 & 2.1 & 2.0 & 1.9 & 2.4 & 2.2 & 2.5 & 3.3 \\
\hline $\mathrm{K}^{+}\left(\mathrm{mg} \mathrm{L}^{-1}\right)$ & $<0.1$ & 0.8 & 4.0 & 2.9 & 4.3 & 2.2 & 2.9 & $<2.0$ \\
\hline $\mathrm{SO}_{4}^{2-}\left(\mathrm{mg} \mathrm{L}^{-1}\right)$ & 1.0 & 0.9 & 0.7 & 0.6 & $<0.5$ & $<0.5$ & $<2.5$ & $<2.5$ \\
\hline $\mathrm{Cl}^{-}\left(\mathrm{mg} \mathrm{L}^{-1}\right)$ & 1.9 & 3.0 & 0.9 & 0.7 & 8.6 & 7.1 & 4.2 & 3.5 \\
\hline $\mathrm{DOC}\left(\mathrm{mg} \mathrm{L}^{-1}\right)$ & 82.0 & 68.0 & 81.9 & 69.9 & 79.6 & 54.0 & 66.2 & 70.5 \\
\hline
\end{tabular}

S. A. Howie and

H. J. van Meerveld

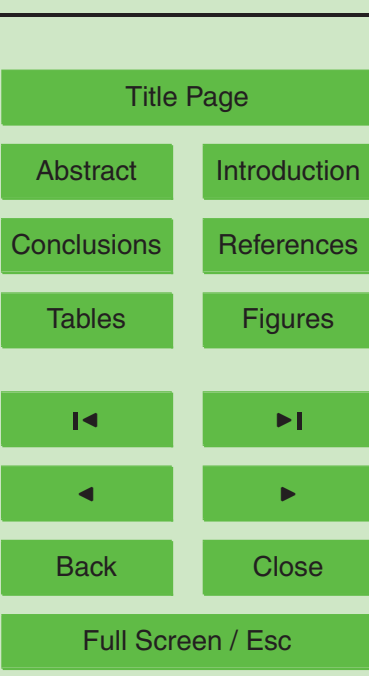

Printer-friendly Version

Interactive Discussion 
Table 6. Ratio of the average concentration in pore water to the average concentration in precipitation. See Table 4 caption for transect codes and Table 1 for sampling dates. Precipitation chemistry sources: (a) Burns Bog and Blaney Bog: YVR 1986-1993 mean (Piteau Associates 1994), (b) Campbell River Bog: Port Hardy 1978-1986 mean (National Atmospheric Chemistry Database, 2012).

\begin{tabular}{|c|c|c|c|c|c|c|c|}
\hline & $\begin{array}{l}\text { Sample } \\
\text { location }\end{array}$ & $\mathrm{Ca}^{2+}$ & $\mathrm{Mg}^{2+}$ & $\mathrm{Na}^{+}$ & $\mathrm{K}^{+}$ & $\mathrm{SO}_{4}^{2-}$ & $\mathrm{Cl}^{-}$ \\
\hline \multirow{15}{*}{$\begin{array}{l}\text { D } \\
0 \\
0 \\
\stackrel{0}{5} \\
0\end{array}$} & SW "Bog” & 3.9 & 14.3 & 6.3 & 38.1 & $<0.3$ & 6.1 \\
\hline & SW "Trans1" & 3.1 & 22.1 & 4.4 & 78.8 & $<0.4$ & 11.3 \\
\hline & SW "Trans2" & 3.7 & 21.4 & 4.3 & 51.6 & $<0.3$ & 7.3 \\
\hline & SW "Lagg1" & 6.3 & 23.6 & 3.2 & 57.2 & $<0.3$ & 10.0 \\
\hline & SW “Lagg2” & 6.9 & 25.7 & 6.7 & 31.9 & 1.6 & 9.0 \\
\hline & SW "Mineral" & 15.4 & 56.4 & 9.1 & 30.0 & 3.8 & 15.4 \\
\hline & DNR "Bog" & - & - & - & - & - & - \\
\hline & DNR "Lagg1" & 10.9 & 10.0 & 9.0 & 33.1 & $<0.3$ & 7.8 \\
\hline & DNR “Lagg2" & 7.4 & 11.4 & 27.2 & 51.9 & $<0.3$ & 15.8 \\
\hline & DNR "Mineral" & 26.9 & 44.3 & 17.0 & 21.3 & $<0.3$ & 9.3 \\
\hline & CW "Bog" & 5.1 & 15.7 & 8.0 & 23.4 & $<0.3$ & 5.8 \\
\hline & CW "Trans1" & 5.1 & 14.3 & 9.3 & 8.1 & $<0.3$ & 8.7 \\
\hline & CW “Trans2" & 7.4 & 17.9 & 4.9 & 28.1 & $<1.1$ & 5.3 \\
\hline & CW "Lagg" & 5.1 & 12.9 & 4.1 & 30.0 & $<0.3$ & 3.1 \\
\hline & CW "Mineral" & 11.6 & 20.7 & 28.1 & 42.5 & - & - \\
\hline \multirow{10}{*}{ 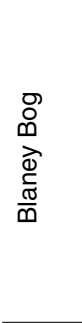 } & BU - "Bog" & 1.4 & $<1.4$ & 1.3 & 4.4 & $<0.3$ & 2.2 \\
\hline & BU - "Trans1" & 0.9 & $<1.4$ & 2.5 & 3.1 & $<0.3$ & 2.3 \\
\hline & BU - "Trans2" & 2.6 & 1.4 & 9.8 & 7.5 & $<0.3$ & 3.7 \\
\hline & BU - "Lagg" & 9.1 & 7.1 & 2.8 & 3.8 & $<0.3$ & 2.2 \\
\hline & BU - "Mineral" & 13.4 & 10.0 & 5.9 & 5.0 & 0.39 & 2.8 \\
\hline & BF - "Bog" & 3.4 & 4.3 & 1.5 & 4.4 & $<0.3$ & 1.8 \\
\hline & BF - "Trans1" & 5.7 & 11.4 & 1.3 & 5.0 & $<0.3$ & 1.8 \\
\hline & BF - "Trans2" & 7.1 & 8.6 & 1.3 & 5.6 & $<0.3$ & 2.2 \\
\hline & BF - "Lagg" & 3.7 & 2.9 & 1.5 & 5.6 & $<0.3$ & 2.3 \\
\hline & BF - "Mineral" & 5.7 & 10.0 & 3.8 & 4.4 & $<0.3$ & 2.8 \\
\hline \multirow{5}{*}{ 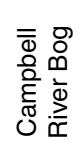 } & CR "Bog" & 8.8 & 3.6 & 3.2 & 24.1 & $<0.5$ & 3.8 \\
\hline & CR "Trans1" & 15.7 & 5.2 & 3.3 & 31.6 & $<0.5$ & 3.8 \\
\hline & CR "Trans2" & 18.6 & 5.7 & 3.0 & 16.1 & $<0.5$ & 2.6 \\
\hline & CR "Lagg" & 23.5 & 8.3 & 4.0 & 38.5 & $<0.5$ & 3.6 \\
\hline & CR "Mineral" & 23.7 & 6.2 & 3.7 & 61.5 & $<0.5$ & 3.1 \\
\hline
\end{tabular}

\section{HESSD}

9, 14065-14107, 2012

\section{Temporal variation in depth to water table and hydrochemistry}

S. A. Howie and

H. J. van Meerveld

Title Page

\section{Abstract}

Introduction

Conclusions

References

Tables

Figures

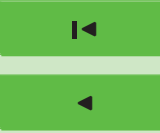

$\rightarrow$

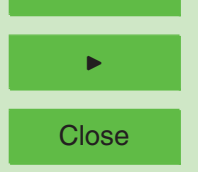

Back

Full Screen / Esc

Printer-friendly Version

Interactive Discussion 


\section{HESSD}

9, 14065-14107, 2012

Temporal variation in depth to water table and hydrochemistry

S. A. Howie and

H. J. van Meerveld

Table 7. Ca: Mg ratios for all transects in June 2011 (May 2011 for Campbell River).

\begin{tabular}{lrrcccc}
\hline & & \multicolumn{2}{c}{ Ca:Mg ratio } & & \\
& "bog" & "trans1" & "trans2" & "lagg1" & "lagg2" & "mineral" \\
\hline Burns Bog - Sherwood & 1.4 & 0.7 & 0.7 & 1.1 & - & 1.3 \\
Burns Bog - Cranwest & 1.9 & 1.5 & 2.0 & 2.0 & - & 1.8 \\
Burns Bog - DNR & - & - & - & 5.4 & 3.3 & 3.0 \\
Blaney Bog - Upland & 5.0 & $>3.0$ & 9.0 & 6.4 & - & 6.7 \\
Blaney Bog - Fen & 4.0 & 3.5 & 4.2 & 6.5 & - & 2.9 \\
Campbell River & 2.4 & 2.5 & 3.3 & 2.7 & & 2.5 \\
\hline
\end{tabular}

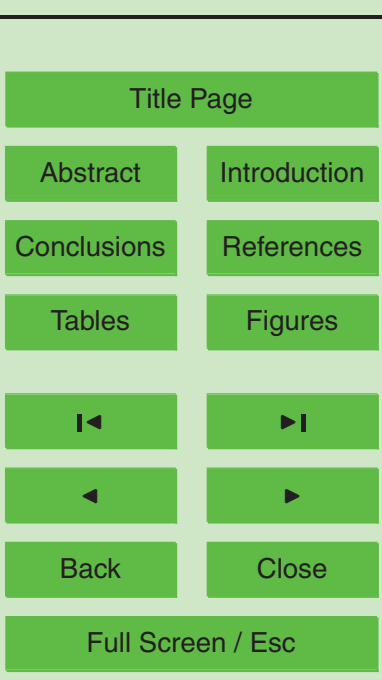

Printer-friendly Version

Interactive Discussion 

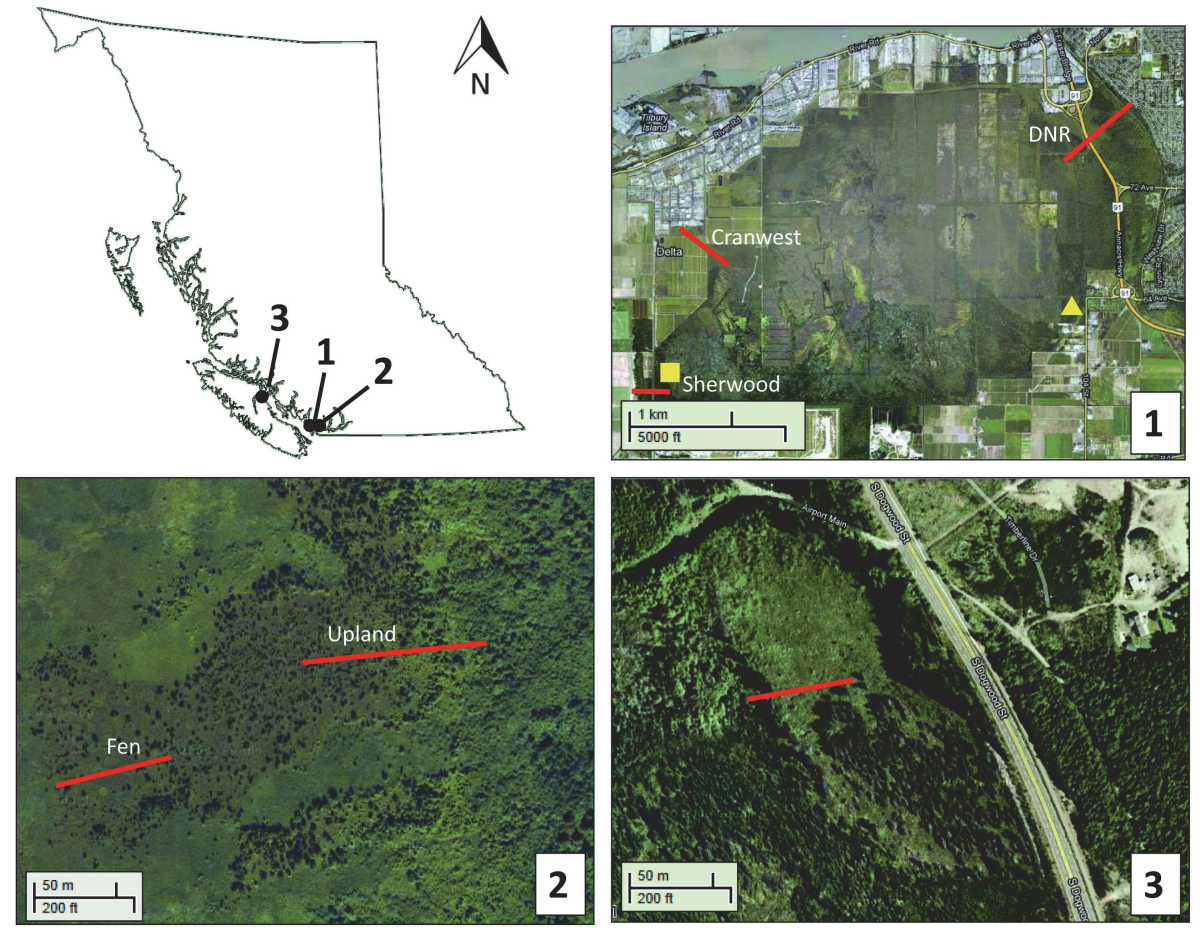

Fig. 1. Location of three research sites in coastal British Columbia: (1) Burns Bog, (2) Blaney Bog, and (3) Campbell River Bog. Red lines represent the transect locations. Additional Burns Bog data are from PF-100 and PF-200 (yellow triangle) and a piezometer near the Sherwood "bog" site (yellow square). Air photo maps from Google Earth.

\section{HESSD}

9, 14065-14107, 2012

\section{Temporal variation in depth to water table and hydrochemistry}

S. A. Howie and

H. J. van Meerveld

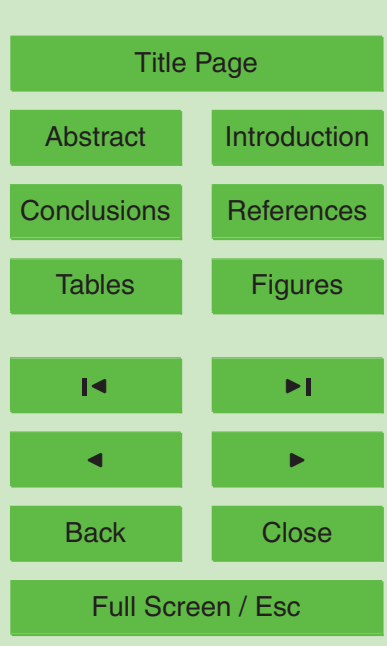

Printer-friendly Version

Interactive Discussion 

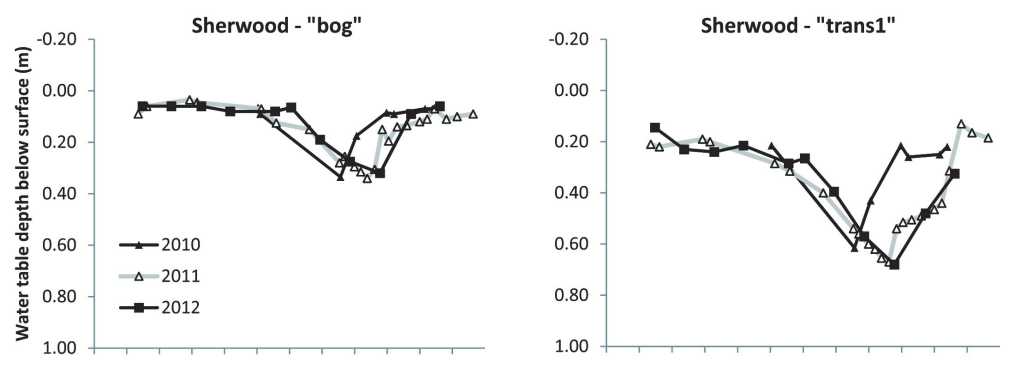

\section{HESSD}

\section{9, 14065-14107, 2012}

Temporal variation in depth to water table and hydrochemistry
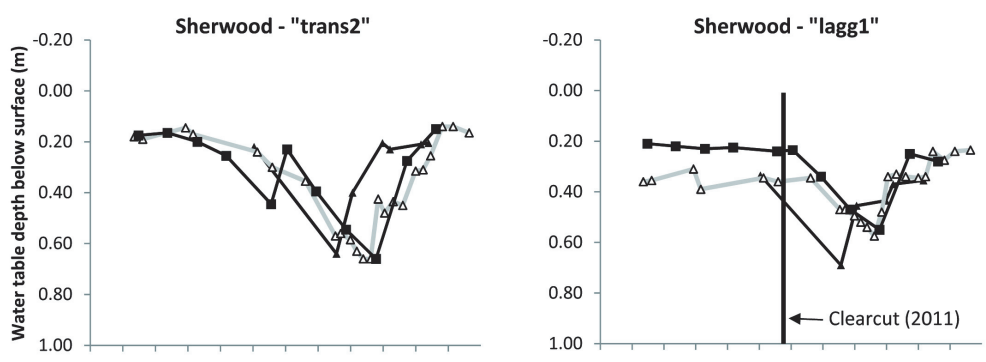

S. A. Howie and H. J. van Meerveld
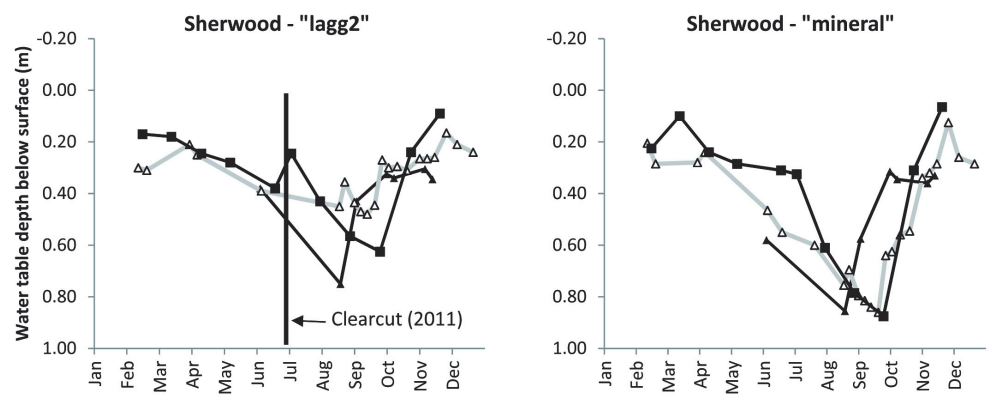

Title Page

Abstract

Introduction

Conclusions

References

Tables

Figures

14

4

Back

Full Screen / Esc

Printer-friendly Version

Interactive Discussion to December 2012. In May/June 2011, logging occurred adjacent to the "lagg1" site; all trees were removed at the "lagg 2" site. 

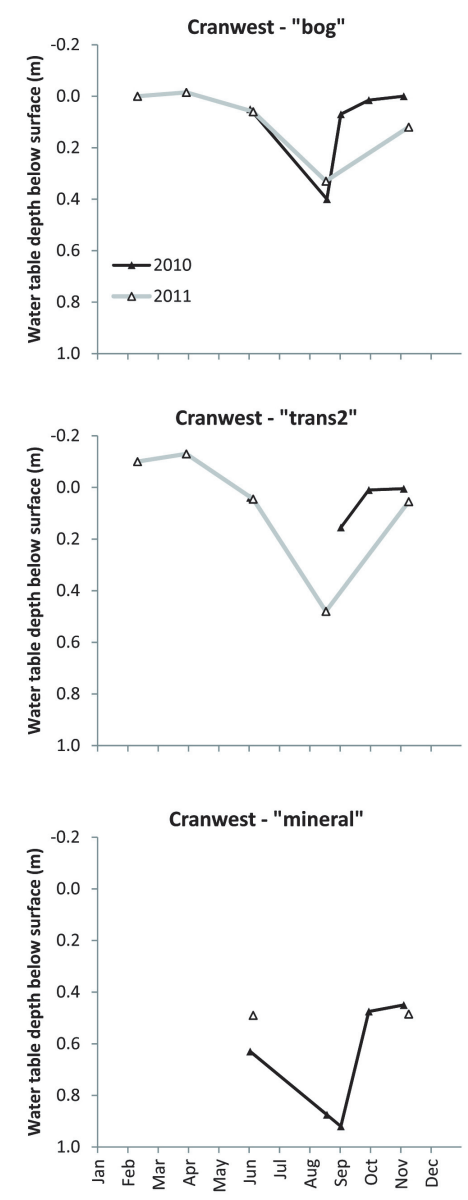

Fig. 3. Time series of depth to water table along the Burns Bog Cranwest transect from June 2010 to December 2011. Negative values indicate that the water table was above the ground surface.
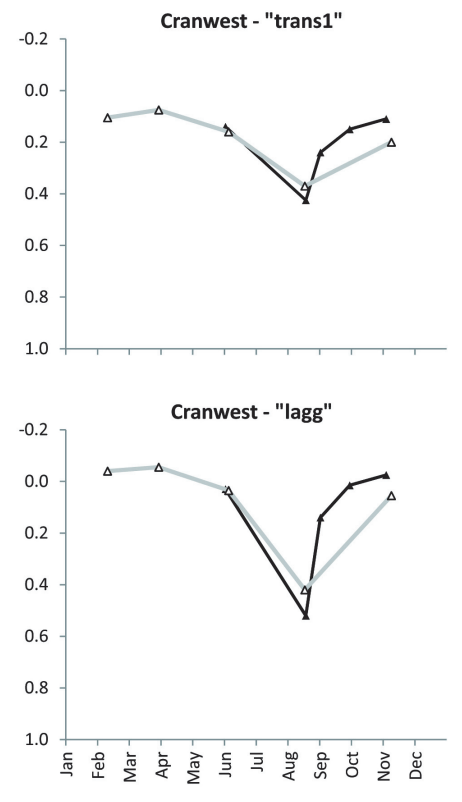


\section{HESSD}

9, 14065-14107, 2012

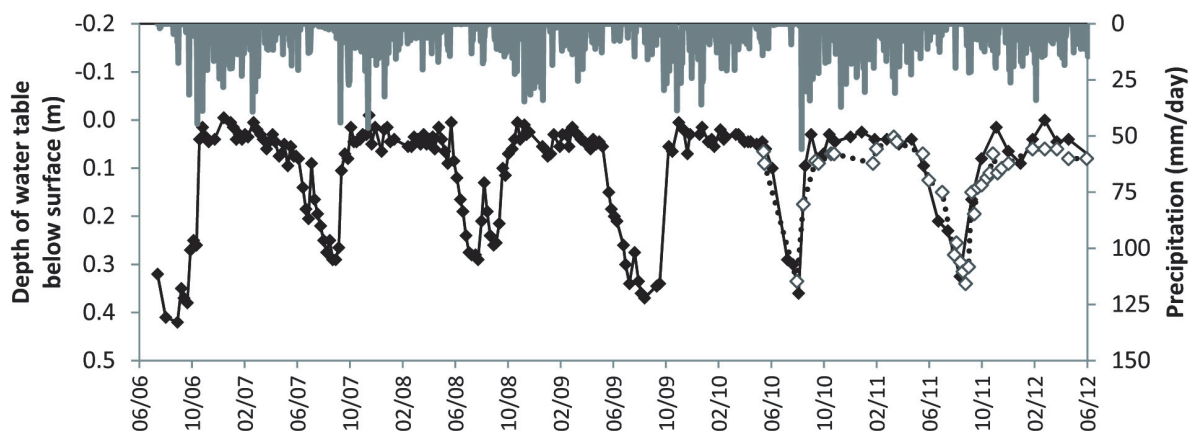

Fig. 4. Depth to water table at the "Sherwood bog" site (dashed line, open diamonds) for the 2010-2012 study period and a nearby piezometer (solid line, solid diamonds) for the 20062012 period. Precipitation (gray bars) was measured at Vancouver International Airport, $15 \mathrm{~km}$ from the Sherwood transect (source: Environment Canada, accessed online 25 July 2012).

\section{Temporal variation in depth to water table and hydrochemistry}

S. A. Howie and H. J. van Meerveld

Title Page

Abstract Introduction

Conclusions References

Tables Figures

14 $\rightarrow$

$\triangleleft$

Back

Close

Full Screen / Esc

Printer-friendly Version

Interactive Discussion 

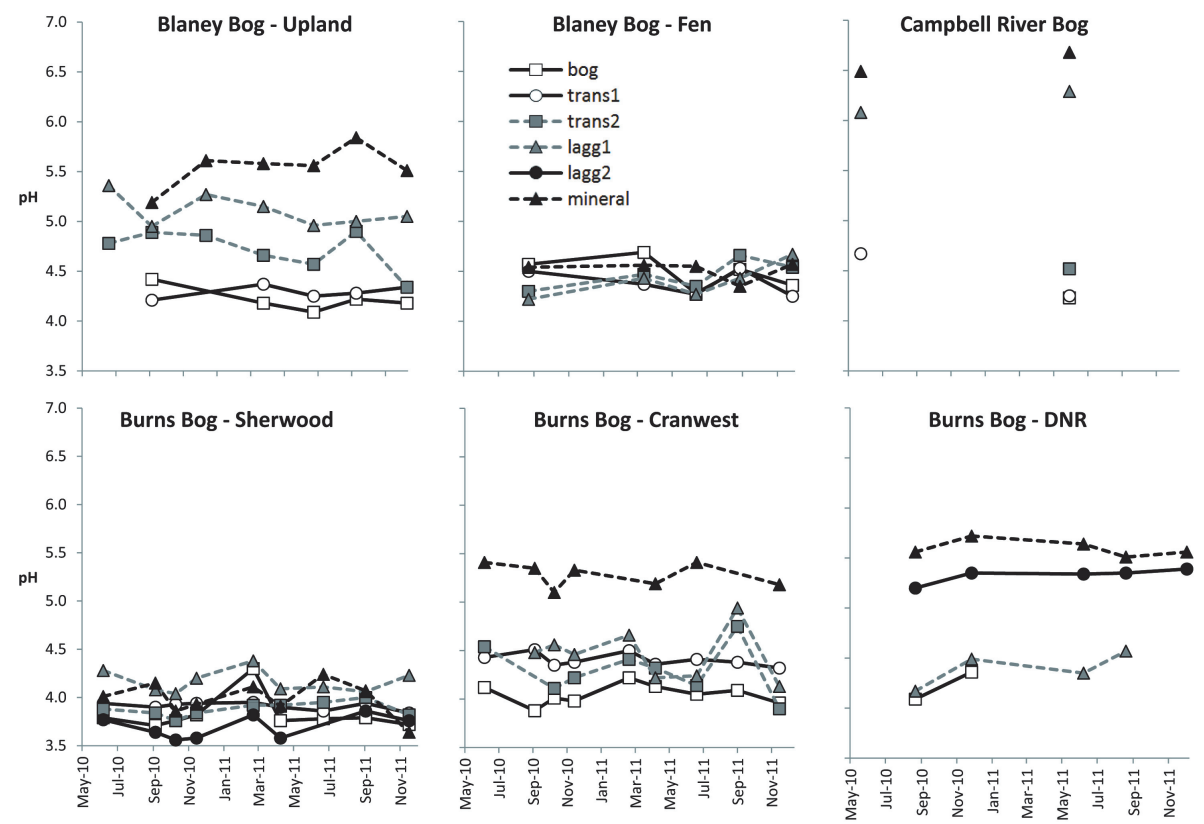

Fig. 5. pH across the six lagg transects from May 2010-December 2011.

\section{HESSD}

9, 14065-14107, 2012

Temporal variation in depth to water table and hydrochemistry

S. A. Howie and H. J. van Meerveld

Title Page

Abstract

Introduction

Conclusions

References

Tables

Figures

14

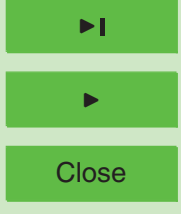

Back

Full Screen / Esc

Printer-friendly Version

Interactive Discussion 


\section{HESSD}

\section{9, 14065-14107, 2012}
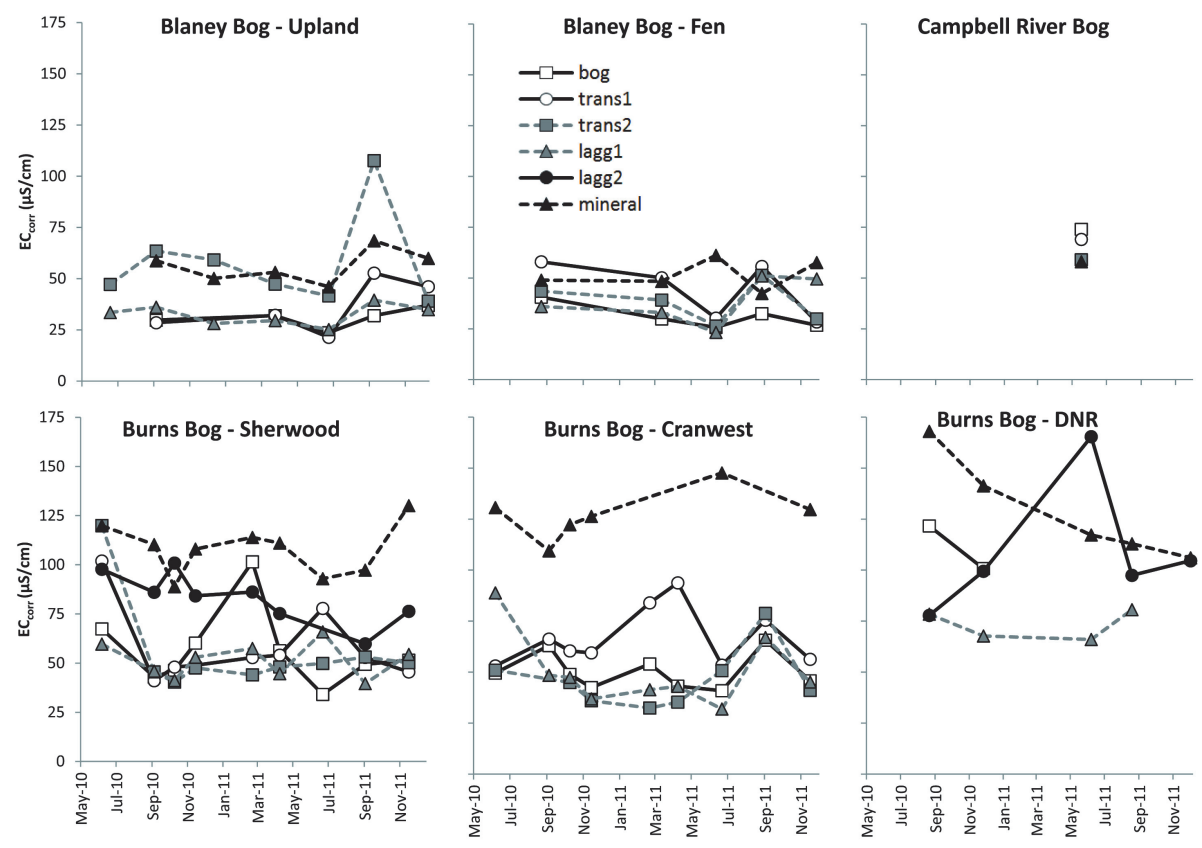

Fig. 6. Corrected electrical conductivity $\left(\mu \mathrm{S} \mathrm{cm}^{-1}\right)$ across the six lagg transects from June 2010-December 2011.

\section{Temporal variation in depth to water table and hydrochemistry}

S. A. Howie and H. J. van Meerveld

\section{Title Page}

Abstract

Introduction

Conclusions

References

Tables

Figures

14

4

Back

Close

Full Screen / Esc

Printer-friendly Version

Interactive Discussion 